\title{
A CASA DE MEMÓRIA DE LEÔNCIO ARARA E OS ARARA DA VOLTA GRANDE DO XINGU ${ }^{1}$
}

\author{
ADALTON FERREIRA DO NASCIMENTO ARARA ${ }^{2}$ \\ ARIAM, BRASIL
}

EDUARDO XAVIER FERREIRA ${ }^{3}$

UFRJ, BRASIL

REGINA POLO MÜLLER ${ }^{4}$

UNICAMP, BRASIL

RENATA UTSUNOMIYA ${ }^{5}$

USP, BRASIL

\begin{abstract}
RESUMO: O texto conta o processo de concepção da Casa de Memória Leôncio Arara, aldeia Terrã Wangã. Terra Indígena Arara da Volta Grande do Xingu, desenvolvida no âmbito de projeto de mitigação de impactos da hidrelétrica de Belo Monte. Verdadeiro historiador, intelectual, curador e guia espiritual, sua liderança foi fundamental na "certificação" da identidade indígena, insistindo-se aqui em usar o termo por ele próprio cunhado. A memória de seus ensinamentos e ações foi o objetivo inicial da constituição da Casa de Memória, conforme a comunidade que, tendo à frente a atual liderança jovem, Adalton Arara, foi concebendo a ideia de um museu indigena no âmbito de atividades de formação em patrimônio cultural. Visitas a museus indigenas de outros povos e curso ministrado por professores indigenas motivaram os Arara a conceber seu próprio museu. E a escolha foi tornar a casa tradicional Arara onde viveu Leôncio Arara, em um espaço expositivo, agenciando autorrepresentação e refletindo a concepção indígena de patrimônio cultural.
\end{abstract}

PALAVRAS-CHAVE: Arara da Volta Grande do Xingu; Museu Indígena; Patrimônio Cultural.

ABSTRACT: The text tells the conception process of the Leôncio Arara Memory House -, Terrã Wangã village, Arara's Big Bend of Xingu Indigenous Land, developed as part of Belo Monte hydroelectric power plant impact's mitigation project. A true historian, intellectual, healer, and spiritual guide, his leadership was instrumental in "certifying" indigenous identity, insisting on using the term that himself coined. The memory of his teachings and actions was the initial objective of the establishment of the Memory House, according to the community that, current guided by the young leader Adalton Arara, was conceiving the idea of an indigenous museum, as

${ }^{1} \mathrm{O}$ presente trabalho foi realizado com apoio da Coordenação de Aperfeiçoamento de Pessoal de Nível Superior - Brasil (CAPES) - Código de Financiamento 001.

${ }^{2}$ Liderança do povo Arara da Volta Grande do Xingu, Presidente da Associação de Resistência Indígena Arara do Maia (ARIAM), Técnico operacional do Plano de Proteção Territorial do Médio Xingu (PPTMX) e formado no magistério indígena pela SEDUC-PA.

${ }^{3}$ Analista Socioambiental e Doutorando em Antropologia Cultural pelo Programa de Pós-Graduação em Sociologia e Antropologia (PPGSA), Instituto de Filosofia e Ciências Sociais, da Universidade Federal do Rio de Janeiro, Rio de Janeiro, Brasil.

4 Doutora em Ciências Humanas/Antropologia (FFLCH/USP) e Professora associada aposentada do Instituto de Artes da Universidade Estadual de Campinas.

5 Analista Socioambiental e Doutoranda em Ciência Ambiental, Instituto de Energia e Ambiente, Universidade de São Paulo (PROCAM-IEE-USP). 
Espaço Ameríndio

part of cultural heritage training activities. Visits to indigenous museums of other peoples and a course taught by indigenous teachers motivated the Arara people to design their own museum. The choice was to turn the traditional Arara's house, where Leôncio Arara lived, in an exhibition space, providing self-representation and reflecting indigenous conception of cultural heritage.

KEYWORDS: Arara of Great Curve of Xingu; Indigenous Museums; Cultural Patrimony. 


\section{Introdução}

Este artigo visa apresentar o processo de concepção de um museu indígena na aldeia Terrã Wangã do povo Arara da Volta Grande do Xingu (VGX). Os Arara ${ }^{6}$ habitam a Terra Indígena (TI) Arara da Volta Grande do Xingu, situada dentro do município de Senador José Porfírio (PA), que foi homologada em 2015 com uma área de 25.524,59 hectares e abriga uma população de 228 pessoas (VERTHIC, 2019; 2018). Sua TI, junto com a TI Paquiçamba, habitada pelos Juruna, são as mais impactadas pelo empreendimento de Belo Monte e encontram-se no Trecho de Vazão Reduzida7 (TVR) do rio Xingu.

A Casa de Memória Leôncio Arara, doravante apenas Casa de Memória, que inicialmente foi concebida para preservar a memória do antigo líder Leôncio Arara, se desdobrou, no decorrer dos projetos de mitigação da hidrelétrica de Belo Monte, em um complexo cultural. Além de traçar seu processo de concepção e desenvolvimento, este texto busca extrair as impressões dos Arara acerca da memória, esquecimento e valorização cultural.

Os dados aqui mobilizados baseiam-se em algumas fontes, principalmente no trabalho de campo desenvolvido durante cinco anos, que permitiu ver o nascimento e acompanhar o amadurecimento dessa ideia até sua transformação em projeto. Recorre-se também a relatórios do Programa de Patrimônio Cultural Material e Imaterial (PPCMI) e publicações que condensam parte dessa experiência ${ }^{8}$ (VERTHIC, 2017a; $2017 b ; 2018$;). Por fim, para a elaboração do artigo foram realizadas entrevistas com lideranças da aldeia Terrã Wangã, por ocasião do acerto dos detalhes finais para se concluir a implantação da Casa de Memória, em setembro de 2019.

Na primeira seção, abordar-se-á a história do povo Arara, desde os antigos Arara do Bacajá até os atuais Arara da Volta Grande do Xingu, com destaque para a pessoa de Leôncio Arara. Na seção seguinte, serão recuperadas algumas influências que os ajudaram a conceber o projeto, sua estrutura e as etapas iniciais de sua implementação. Em seguida, buscar-se-á descrever a casa e seus anexos e o acervo e disposição dos objetos, visando, com isso, delinear algumas concepções Arara acerca do patrimônio cultural. A penúltima parte do texto recupera os objetivos da

\footnotetext{
${ }^{6}$ Sabe-se que esse termo é utilizado para designar uma variedade de povos indígenas das terras baixas da América do Sul. Para fins deste artigo, entretanto, o uso desse termo designará preferencialmente os Arara da Volta Grande do Xingu. No caso de menção a povos que também atendem por essa designação serão devidamente distinguidos.

${ }^{7}$ O TVR compreende um trecho de $130 \mathrm{~km}$ de extensão da região da Volta Grande do Xingu no qual a vazão do rio sofreu redução para o aproveitamento hidrelétrico de Belo Monte. Ambas as TI estão situadas entre os dois barramentos que compõem o empreendimento. Situada a montante, a barragem do Pimental é responsável por represar e desviar maior parte do curso d'água por um canal de derivação até o segundo barramento, a hidrelétrica de Belo Monte, que está à jusante das TIs. Neste é gerado quase a totalidade da energia elétrica do empreendimento (VERTHIC, 2018).

${ }^{8}$ Tanto o trabalho de campo aqui mencionado, realizado desde setembro de 2014 e totalizando 44 meses de atividades na TI Arara da Volta Grande do Xingu, quanto as publicações, foram desenvolvidas no âmbito das ações de compensação e mitigação que constam no Projeto Básico Ambiental - Componente Indígena (PBA-CI) da hidrelétrica de Belo Monte.
} 
Casa de Memória sob novas evidências. Melhor informados pelas discussões anteriores, é possível perceber que a preservação da memória de Leôncio Arara por meio da Casa de Memória é um esforço de tornar objetivo um conjunto de relações que ali foram tecidas, sendo o espaço que condensa as origens dos Arara, seu antigo modo de vida, sua cultura material e imaterial, assim como um laboratório de sua projeção para o futuro. Nas considerações finais, arrisca-se a sugerir que o patrimônio cultural do qual Leôncio Arara era seu guardião é eleito como um meio de garantir a continuidade e singularidade do grupo Arara, agenciando autorrepresentação tanto para as gerações futuras, quanto afirmação étnica para fora da aldeia.

\section{Leôncio Arara e a história dos Arara da Volta Grande do Xingu}

Abordar a história dos Arara é, de certa forma, abordar a história de um personagem de grande importância na vida desse povo, Leôncio Arara. Sua trajetória pessoal foi fundida à história do grupo, servindo de verdadeiro elo entre o passado e o presente, entre os antigos Arara do Bacajá e os atuais Arara da Volta Grande do Xingu. Nesta sessão, procuraremos retomar parte da história recente desse povo e destacar a importância de Leôncio Arara como seu guardião e difusor.

$\mathrm{Na}$ literatura, os Arara do Bacajá foram identificados como um dos subgrupos Arara que circulavam pelo vasto território compreendido desde o rio Tocantins até o rio Iriri, importante afluente esquerdo do rio Xingu, alcançando, inclusive, a bacia do rio Amazonas. Falantes da língua Arara, pertencente à família linguística Caribe, com exceção dos Arara da Volta Grande do Xingu onde a língua corrente é o português regional, eles estão divididos em três TI: Arara, Cachoeira Seca e Arara da Volta Grande do Xingu.

Além de povos Caribe, a região ocupada pelos Arara faz parte de um grande espaço de circulação de povos falantes do tronco linguístico Tupi, incluindo famílias Tupi-guarani, Juruna e Munduruku, e Macro-jê, língua Kayapó. Durante a colonização do norte do país, essa região recebeu diversas investidas por parte dos colonizadores que se aventuravam cada vez mais Brasil adentro em expedições de apresamento e redução de indígenas para suprir a mão de obra na capitania do Maranhão - que englobava parte dos atuais estados do Pará, Maranhão e Ceará. Esses esforços para alimentar as crescentes lavouras do litoral da colônia foram sustados por períodos em que a função de redução era delegada aos jesuítas. Assim, os indígenas reduzidos, em vez de serem conduzidos às lavouras do litoral, eram aldeados e catequisados. Em ambas as situações, eles eram expostos a grandes violências e doenças que dizimavam boa parte dessas populações (VIVEIROS DE CASTRO, 1986; FAUSTO, 2001). Desde o séc. XVII, por exemplo, já há registro dos Juruna interagindo na borda da expansão da colônia, resistindo ou se engajando nelas (NASCIMENTO, 2017). Apesar dos esforços da colonização para superar significativas barreiras, a região pedregosa e de difícil navegação da Volta Grande do Xingu e, principalmente, o complexo de cachoeiras 
do Jericoá (ou Jurucuá), dificultou a instalação e atuação direta dos invasores europeus na região acima dela. Entretanto, a região não esteve a salvo de doenças que se propagavam e que provavelmente atingiram as populações que ali habitavam. Em meados do séc. XIX, esse processo culminou no enfraquecimento geral dessas populações, com 0 rompimento de redes supralocais, restando grupos dispersos e relativamente isolados entre si (FAUSTO, 2001).

É justamente nesse período, mais precisamente em 1853, que se têm as primeiras notícias de um povo denominado Arara ${ }^{9}$ no baixo Xingu. Ao longo do séc. XIX eles foram vistos outras três vezes. Em 1861-62, quando desceram em direção às margens da Volta Grande do Xingu, estabeleceram por algum tempo contato pacífico com seringueiros até que, após um confronto com os Juruna, retornaram às matas (NIMUENDAJÚ, 1948). As relações de hostilidade entre os dois povos permaneceram, sendo, inclusive, reportada por Karl Von de Steinen, em 1884, a presença de um prisioneiro Arara em uma aldeia Juruna no Xingu (STEINEN, 1940 [1884]). Anos mais tarde, em 1896, por ocasião da expedição de Coudreau ao rio Xingu, há a menção a uma antiga aldeia Arara entre a Volta Grande do Xingu e o Igarapé Piranhaquara (afluente do Xingu à montante de Altamira, atualmente localizado dentro da TI Koatinemo do povo Asuriní do Xingu), assim como a grande mobilidade desses grupos, que transitavam desde o rio Tocantins até o rio Curuá, afluente do rio Iriri (COUDREAU, 1977 [1986]). Já Oliveira (1970, p.31) comenta relações pacíficas entre os Juruna e os Arara no final do século XIX, e Krautler (1953, p.5-6) cita que em 1894, um maranhense chamado "Braúna" chegou até a cachoeira da Piranhaquara e lhe disse que:

na ilha dentro do lago de Piranhaquara, havia então uma maloca dos índios Juruna, cujo tuchaua ${ }^{10}$ chamava-se 'Macaiary' mas que era da tribo dos Arara, com os quais os Juruna viviam em grande amizade (...) ao todo a maloca contava 142 pessoas.

Dois anos depois, o mesmo Arara é citado por Coudreau (1977[1986]), com o nome de "Macairi", um dos tuxáuas das 16 malocas Juruna encontradas pelo francês.

É ainda no século XIX que a região do médio Xingu observa a chegada dos Mebêngôkre, o que causou uma grande reorganização espacial. Na tentativa de evitar novos confrontos com os Gorotire, levas sucessivas de grupos Xikrin alcançam a bacia do rio Bacajá e do rio Xingu atingindo diversos povos indígenas que por lá estavam. Entre eles encontram-se os Araweté, Asuriní, Parakanã, Arara e também nãoindígenas. Conforme já mencionado, é possível considerar que a situação em que se encontravam os povos que ali perambulavam, eram de grupos

\footnotetext{
${ }^{9}$ É importante ressaltar que o nome Arara aplicado a essas populações Caribe é um heterônimo. Os Arara das TI Arara e Cachoeira Seca se autodenominam Ugoro'gmo que, segundo Iaut Arara (comunicação pessoal, 2017), quer dizer "todos nós" (TEIXEIRA-PINTO, 1997).

10 “Tuchaua" ou "tuxaua" são modalidades recorridas por viajantes para se referir aos líderes indígenas de determinado grupo local ou aldeia (NASCIMENTO, 2017).
} 
pouco numerosos e enfraquecidos, o que favoreceu a expansão dos Mebêngôkre, cujos atuais representantes na região são os Xikrin do Bacajá e os Kayapó-Kararaô (GORDON, 2006; VERSWIJVER, 1992). A chegada desses últimos causou um efeito cascata em que um povo, atingido e desalojado, fugia das investidas dos recém-chegados e acabava encontrando com outros, acirrando as guerras na região (XAVIER FERREIRA, 2018). Essa situação de fragilidade foi confirmada pelos relatos de Leôncio e Ananum Arara, de que sempre eram poucos e que eram alvos constantes de ataques de outros povos e de doenças ${ }^{11}$ (PATRíCIO, 2005). Essa situação de constantes guerras só veio a arrefecer após o último quarto do século XX, quando os povos da margem direita do rio Xingu estabeleceram, forçosamente ou não, contato definitivo com a sociedade nacional.

Antes desse período, porém, Nimuendajú, por exemplo, identificou diversos subgrupos Arara que transitavam desde a margem esquerda do Iriri à margem direita do Bacajá. O subgrupo localizado na margem do rio Bacajá (Figura 1, item 4) são os antepassados diretos dos Arara da Volta Grande do Xingu, conforme relatado por Leôncio e Ananum Arara (NIMUENDAJÚ, 1948; VERTHIC, 2017; PATRÍCIO, 2005). Na Figura 1 estão destacados os locais em que foram registradas a presença dos Arara e as datas dos respectivos encontros. Cobrindo o período de 1861 , segundo avistamento dos Arara, até 1987, contato definitivo do último subgrupo em isolamento na época, é possível observar o grau de dispersão dessa população.

De maneira geral, nos relatos de Coudreau (1977 [1 896]), TeixeiraPinto (1997) e Nimuendajú (1948), os Arara são descritos como um povo de "dentro da mata", de terra firme. O que auxiliava a identificação desses diversos subgrupos Arara como pertencentes ao mesmo povo eram as flechas compridas e os troféus de guerra como escalpos, crânios, orelhas, colares de dentes e faces humanas destacadas. O "poste cerimonial" chamado de Jeipari, "pau-amigo" na língua Arara, utilizado em ritual homônimo, era um importante elemento (TEIXEIRA-PINTO, 1997; NIMUENDAJU, 1948). Da mesma forma, a armação necessária para extração da palmeira inajá de uma de suas bebidas rituais, a aremko.

A produção do aremko requer uma tecnologia mais complexa. Grandes armações de madeira servem de andaime para se atingir o topo das árvores, onde se perfura o centro do caule e se afastam as largas folhas para que o sol possa incidir mais diretamente. Como normalmente as palmeiras ocorrem em nichos, longas varas de bambu ou troncos de árvores finas são dispostas no alto, fazendo pontes entre uma palmeira e outra. O cenário nos locais de produção de aremko é inconfundível: por entre as armações, os homens se divertem subindo e transitando entre os cumes das

\footnotetext{
11 Esse parece ter sido uma condição que muitos povos tiveram de enfrentar nesse período. Para uma situação parecida $c f$. Müller (1993), Silva e Noelli (2015) e Xavier Ferreira (2018) para o caso dos Asuriní do Xingu.
} 
árvores, de onde sacam com finos bambus o líquido que se acumulou no centro de caule que fermentou naturalmente pela ação direta do sol. O aremko é uma bebida da estação chuvosa (TEIXEIRA-PINTO, 1997, p. 58-59).

Figura 1: Mapa de contatos do povo Arara.

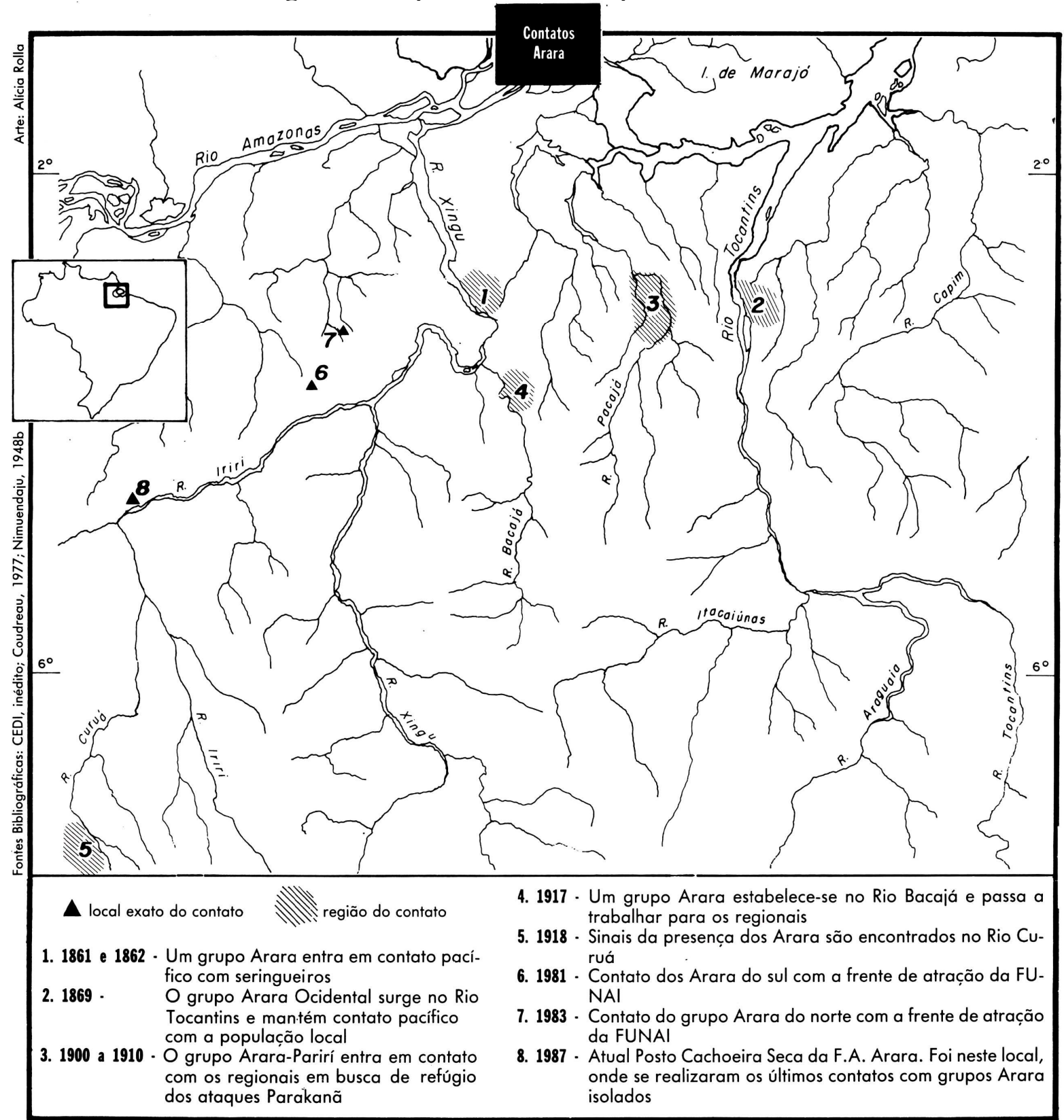

Fonte: Viveiros de Castro e Andrade (1988).

O uso dessa bebida, também conhecida como "caxiri de inajá" na Volta Grande do Xingu, e seu modo de extração são uma das evidências que ligam os Arara dessa região como descendentes de um dos subgrupos Arara. Os anciões Juruna e Arara da Volta Grande ainda guardam na lembrança as armações feitas próximo às malocas dos avós e pais de Leôncio e Ananum Arara (VERTHIC, 2017a, p. 13). 
Os antepassados dos atuais Arara em questão, os antigos "Arara do Bacajá" se instalaram definitivamente na região da Volta Grande do Xingu próximo da virada do século XX. A partir de informações coletadas por Patrício (2005), foi possível retraçar sua chegada e identificar pelo menos dois subgrupos a partir de dois informantes principais, Ananum e Leôncio Arara.

Ananum, primo de Leôncio, narra a descida de um subgrupo de cerca de 50 pessoas pelo rio Bacajá por meio de uma canoa (ubá). O deslocamento da avó de Ananum (Tjeli) ocorreu a partir de Morro Pelado, localidade do médio curso do rio Bacajá, até a ilha Barra do Vento, localizada na Volta Grande do Xingu. Dos 50 indígenas que de lá saíram somente 20 chegaram, pois, a fome e a gripe ceifaram a maior parte do grupo. Assim que lá chegaram, foram expulsos por um seringueiro que já habitava o local. Seu percurso acabou na localidade conhecida como Samaúma, local que se encontra dentro da atual TI, próximo da aldeia Terrã Wangã, entre esta e a foz do rio Bacajá. Já o avô de Leôncio, Pirá Arara se deslocou, com seu grupo, de sua maloca que ficava à margem esquerda do Igarapé Sucuriju em direção ao Xingu. Na foz, pararam próximo à maloca de Mïratu ${ }^{12}$ Juruna, num local conhecido como Chico Tintim, abaixo da ilha do Deserto nas proximidades das cachoeiras do Jericoá. Tanto Ananum quanto Leôncio dizem que assim que seus avós chegaram na região da atual TI já encontraram pelo menos três brancos que lá viviam, Vicente Cearense, Pedro Ferraz e Feliciano (PATRÍCIO, 2005).

Não se pode deixar de notar que as uniões entre os Juruna e Arara já vêm de longa data. Não obstante, a chegada definitiva na Volta Grande do Xingu ampliou o campo de parceiros matrimoniais para os nãoindígenas também. Na opinião de Fortunato Juruna, um dos netos de Mïratu Juruna, a mãe de Leôncio era também Juruna e não Arara, conforme afirmava o segundo. Este último, munido do conhecimento da trajetória do igarapé Sucuriju até a Volta Grande, assim como a longevidade da união Juruna-Arara, reconhecia a possibilidade de os descendentes herdarem as duas identidades. Entretanto, em determinado momento de sua vida ele passou a privilegiar a identidade Arara em detrimento da Juruna. Por outro lado, o fato de se "certificarem" como Arara não quer dizer que são ou querem ser como os parentes da TI Arara e Cachoeira Seca. Segundo Leôncio:

somos como somos e não negamos, tem preto e tem branco (...) mas também somos parente de todo esse povo que Ihe falei que andou com minha mãe Firma, meu avô Pira e minha avó Tintim e que viveram aqui (PATRÍCIO, 2005, p. 13-14).

Assim, desde quando aportaram na Volta Grande do Xingu, os Arara rapidamente se relacionaram com as populações que ali habitavam, inclusive os Juruna e não-indígenas, e também participaram dos ciclos de

${ }^{12}$ Um dos 16 chefes de malocas Juruna na ocasião da viagem de Coudreau ao Xingu (Coudreau, 1977 [1896]) e cujos descendentes atualmente habitam a TI Paquiçamba. 
exploração econômica da região: extração de seringa, exploração de castanhais, caça a pele de gatos e lontras, comércio de peixes, garimpo, etc. Após a abertura da Transamazônica, o Instituto Nacional de Terras (INCRA) iniciou, em 1975, um projeto piloto de colonização e cadastro de lotes na área ocupada por Leôncio e seus parentes. Essa pressão se fez sentir com a chegada de mais não-indígenas na região, acirrando conflito sobre uso de terras. Uma das consequências dessa mudança foi a migração de parte de indígenas da Volta Grande do Xingu para a cidade de Altamira.

Nesse período, Leôncio Arara chegou a se cadastrar junto ao INCRA, mas não foi contemplado. Consciente das ameaças ao seu antigo território de ocupação, acentuada com a vinda da hidrelétrica de Belo Monte, cujos estudos continuavam em andamento, passou a reivindicar junto à Fundação Nacional do Índio (Funai) o reconhecimento da ocupação e legalização da posse da terra. Com o apoio do Conselho Indigenista Missionário (CIMI), Leôncio e José Carlos Arara, seu neto, vão ao I Encontro Nacional Povos em Luta Pelo Reconhecimento Étnico e Territorial, realizado em Olinda, Pernambuco, em 2003. Os estudos para demarcação da TI Arara da Volta Grande do Xingu - autodenominação que se constrói no processo de identificação e delimitação - foram iniciados em 2004, tendo sua declaração de posse sido emitida em 2008. Sua homologação, porém, veio apenas em 2015, como uma das medidas compensatórias pela implementação da hidrelétrica de Belo Monte. Um dos guardiões da história dos Arara, Leôncio foi peça fundamental no processo demarcatório da atual TI Arara da Volta Grande do Xingu e no reconhecimento da identidade indígena, ou na "certificação", termo por ele próprio cunhado.

Além de importante liderança política e um dos anciões da Volta Grande do Xingu, Leôncio Arara foi um curador de renome na região. Também conhecido por Seu Nego, suas orações e remédios naturais foram responsáveis pela cura de muitas pessoas da região, indígenas e não-indígenas, e até dos municípios próximos, como Altamira e Vitória do Xingu. Apesar de ser chamado por todos da Volta Grande do Xingu de pajé, ele se considerava curador e "homem florestal", pois seu conhecimento e poder de cura tinham por referência as plantas da floresta.

Nesse quesito, segundo os interlocutores, é difícil encontrar alguém que não o conhecesse ou mesmo que não tivesse sido curado por ele. Suas operações de cura eram baseadas na fé, em ervas e orações. Outra importante característica sublinhada por seus parentes era a recusa de pagamento pelas curas efetuadas. Seu código de conduta não o permitia, pois dizia que seu dom era apenas para curar e ajudar pessoas.

Vinha era de todas essas aldeias, todas as aldeias, dessas aqui da Volta Grande [do Xingu], tudinho aqui, [rio] Bacajá aí pra cima, o pessoal que não era indígena. O vô colocou muita gente lá em Altamira bom. Altamira também. Ele tinha uma mulher lá em Altamira que ela tava com um cisto e ele fez um remédio pra ela, eu nem 
sabia que ele sabia fazer, que ele não falava. Aí ela doente, aí ele fez um remédio pra ela lá. Aí ela foi tomando o remédio e quando ele ia pra rua, que ele ia de mês em mês, ele já levava as garrafada que dava pra ela tomar o mês certinho pra quando for o outro mês ele ia e tomar de novo. Aí ele foi fazendo o tratamento, sei que ele tratou dela, durante 6 mês ele fazendo isso (...) Ele curava muitas pessoas. Não era só nós aqui não, os índios vinha, os outros, aqui do Paquiçamba, Mïratu, Furo Seco13, tudo vinha pra ser curado com ele. (JOSELHA ARARA, 2019, p. 9).

As curas eram realizadas em dois momentos principais, de manhã, até às 08 horas, e no final da tarde, das 17 às 18 horas. Entre as diversas doenças que Leôncio curava, as mais recorrentes eram peito aberto, espinhela caída, criança com quebrante, mau olhado, vermelha, entre outras. Nessas ocasiões, sua residência e as imediações ficavam repletas de pessoas que iam ser tratadas por orações, pegar remédios ou mesmo pedir conselhos. Suas proezas no campo da cura eram tamanhas a ponto de a farmácia da aldeia ser pouco utilizada.

De fato, seu Leôncio, por seu conhecimento da história do povo Arara e da Volta Grande como um todo, suas habilidades curadoras e sua luta política pelo reconhecimento de sua identidade indígena transformou-se em uma referência para outras populações da região e principalmente para seu povo de tal modo que muitos o consideravam como um pai.

Ave Maria. A minha história com Leôncio é também assim, é que ele foi embora, mas o amor nunca acaba, pra mim não. Que nem a Nega [Joselha Arara] tava falando aí, pra mim ele se acabou, morreu, mas pra mim ele tá vivo direto, porque a gente nunca consegue esquecer. É que nem quando a gente tá nas própria reunião, usa pra tudo, né Nega [Joselha Arara]? Usa o nome dele pra um bocado de coisa. Aí, não consegue esquecer porque foi uma pessoa muito batalhadora pra hoje nós tá aqui. Foi linha de frente, né, esclareceu tudo, botou tudo na verdade aí. Hoje a gente agradece muito. Pra mim foi um pai, até porque foi, fui cria deles também (...). Muito forte, era um pai forte, deixou saudade e essa saudade pra quem é vivo não acaba não. (ARLINDO ARARA, 2019, p. 4).

Todas essas qualidades e seu histórico de vida o transformaram em uma peça central no destino do povo Arara da Volta Grande. Ele "era o pajé, chefe geral da terra, porque quando se tem um pajé, geralmente é o pajé que manda na terra toda, né. Ele é quem sabe das ordens espirituais, sabe curar todo mundo e aí ele tinha essa importância para

\footnotetext{
${ }^{13}$ Aldeias pertencentes a TI Paquiçamba do povo Juruna.
} 
nós, era muito grande." (ADALTON ARARA, 2019, p. 2). Ou, como ele próprio dizia, o "reis" do local.

É, que, na verdade, eu sempre ouvia ele dizer assim que "eu sou o reis daqui", ele dizia. (...) Mas aí eu fiquei pensando, por que que ele dizia isso? Eu achava porque ele queria ser, (...) mas depois eu fiquei pensando, é tão ruim quando você faz alguma coisa, você briga, você tá ali na frente, defendendo, defendendo, defendendo, defendendo, e você não tem o reconhecimento das coisas suas. Eu não digo nem só na questão (...) da gratidão, mas eu digo numa questão histórica, num contexto histórico, né. Porque foi ele que fundou essa aldeia. Enquanto outros irmãos construíram família em outros cantos, ele ficou aqui com a Dona Cema, teve os filhos, os filhos casaram, teve os neto, os netos casaram. Ele ficou sozinho aqui, então isso aqui foi ele que construiu, né. E aí, na questão histórica do povo (...) as vezes passava batido, né, a importância dele. Não só na questão histórica, como na questão da medicina, do conhecimento tradicional que ele tinha. Às vezes você tava com um problema, uma dor de barriga, uma dor de cabeça, que tem coisas que do corpo que a gente sabe que o médico não dá jeito (...) a gente apelava pra medicina natural, que, na verdade, seria o melhor, né, se todo mundo soubesse. E aí, tudo isso foi passado, ia sendo passado, muita coisa se perderam. Ele levou consigo porque não deu tempo, né. E ele sempre falava que a pessoa pra curar, pra cuidar do outro, ele tem que ter boa vontade. Nada pode ser feito de má vontade ou por obrigação e nem por dinheiro, você tem que ter boa vontade. Ele via que aqui num contexto, as pessoas estavam tão ligada em dinheiro, em divisão, intriga por causa de dinheiro, relacionado, né, principalmente por causa de Belo Monte. As famílias se desfizeram, então as pessoas não tavam mais preocupadas com a cultura, estavam preocupadas em conseguir bens, em conseguir infraestrutura." (LÍDICE JURUNA, 2019, p. 2-3).

\section{Origens e projeto da Casa de Memória Leôncio Arara}

A constituição da Casa de Memória Leôncio Arara teve origem na ideia de preservar a memória desse líder, conservando a sua casa e o terreiro ao lado, locais onde costumava permanecer durante todo o dia e através dos quais a comunidade relembra sua presença. Após conversas e planejamentos entre seus descendentes, a ideia expandiu para um complexo cultural que compõe o projeto da Casa de Memória, a saber: a moradia de Leôncio Arara, feita de madeira e coberta de palha de babaçu com o terreiro ao lado da casa, onde há pedras do fogareiro para assar alimentos e onde passava a maior parte do tempo; um anexo, ao lado da 
moradia, compreendido por uma casa de madeira reformada e antiga farmácia da aldeia, que abrigará objetos e demais materiais expositivos; e outro anexo ao lado deste, uma construção de alvenaria, antiga escola da aldeia, que será a Casa de Artesanato. A memória de seus ensinamentos e ações é o objetivo inicial e principal de constituição da Casa de Memória, conforme a comunidade foi concebendo a ideia de um museu indígena, tendo à frente a atual liderança jovem, filho de criação e coautor do presente artigo, Adalton Arara.

Figura 2: Três prédios que compõem o Complexo Cultural Leôncio Arara. Da direita para esquerda: casa de Leôncio Arara, o anexo expositivo e a casa de artesanato.

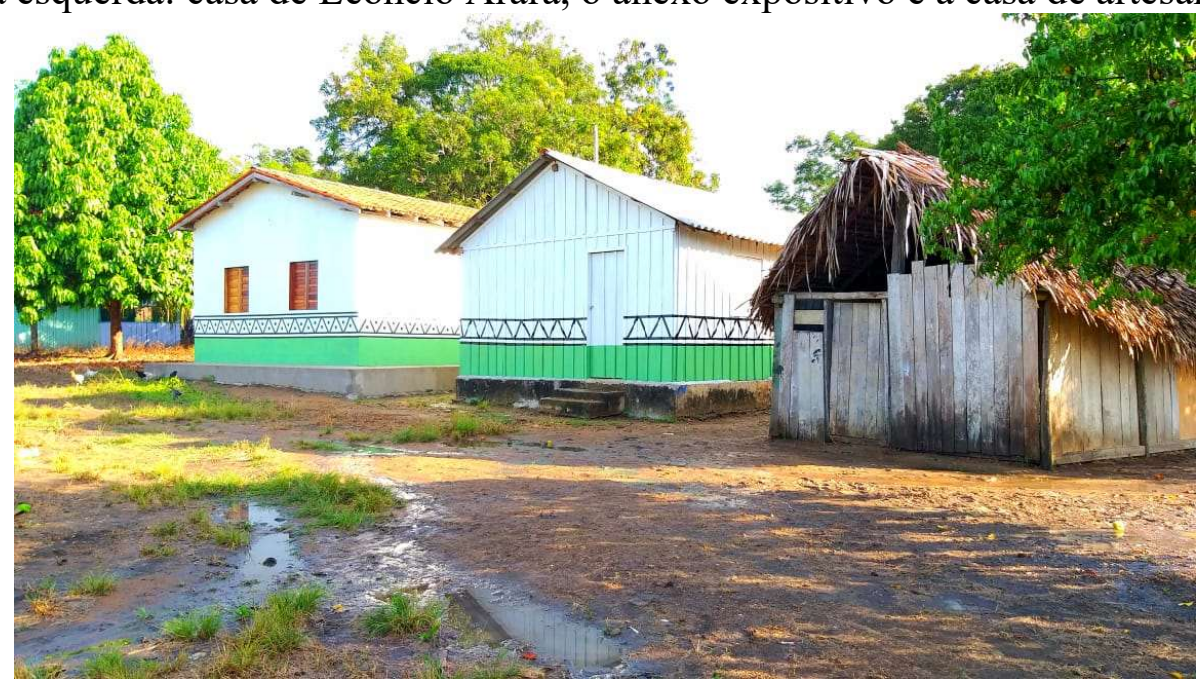

Foto: Renan Arnault, 2019.

O processo que culminou na criação do complexo cultural envolveu diversas influências que aqui serão mapeadas. Momentos importantes desse processo foram as etapas que se sucederam após o falecimento do ancião. Nessa ocasião, a viúva Iracema dos Passos, mais conhecida como Dona Cema, que relutava em deixar a sua casa, é convencida pelos filhos a mudar para a nova residência de alvenaria, junto com o filho Luís Arara, com a promessa de não derrubarem a casa e transformá-la em uma casa de memória. Concebeu-se, assim, que ela será, por si própria, objeto de exposição do espaço museal. Nela, Leôncio costumava dormir na cozinha e Iracema dormia no quarto onde há vestígios de duas peças de cerâmica enterradas no chão. São artefatos arqueológicos proibidos por ele de serem tocados ou retirados. Estes vestígios serão sinalizados para comporem o espaço expositivo. Objetos como bordunas, remos e lanças produzidos por Leôncio serão colocados na casa e as plantas utilizadas para remédio permanecerão pendurados na cozinha, de onde nunca foram retirados desde seu falecimento, após decisão da comunidade. Em janeiro de 2019, foi realizado um mutirão para reforma da cobertura de palha da casa, realizando reparos nos esteios e trocando a palha da cobertura, que já estava com goteiras. 
Figura 3: Sacolas com plantas usadas para remédios do mato e cestos de fibra vegetal.

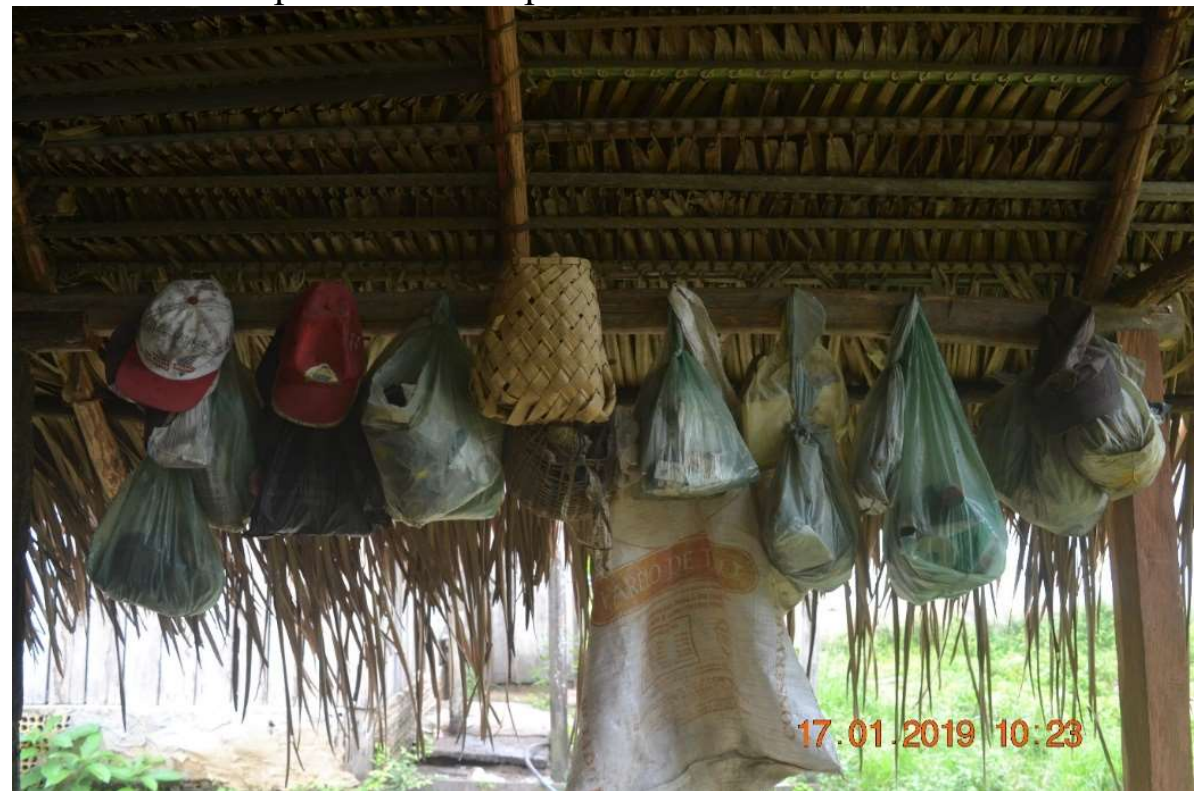

Foto: Renata Utsunomiya, 2019.

O anexo da casa de memória foi necessário ao projeto, pois o acréscimo de outros objetos no interior da moradia, além dos pessoais de Leôncio, a descaracterizaria. Além disso, não haveria espaço suficiente para colocar todos os artefatos selecionados para exposição e não seria um espaço adequado para expor fotos e vídeos que complementam a estratégia expositiva para preservar a memória da vida de Leôncio e da história do povo Arara. Esse material é o registro de narrativas, festejos, produção de artefatos, benzimentos, demais atividades do ancião e da comunidade e fatos históricos. Tomada a decisão, foi planejada e executada uma reforma da casa de Leôncio Arara - pois estava em condições precárias -, trocando-se as paredes e o telhado. Durante a execução da reforma, foi elaborado o projeto expositivo pelo arquiteto Eurico Ugaya, a partir das informações organizadas pela equipe técnica do Programa de Patrimônio Cultural Material e Imaterial' ${ }^{14}$, o qual foi apresentado e aprovado pela comunidade em abril de 2019. No projeto expositivo, a casa de Leôncio Arara terá sinalizações e placas descrevendo os espaços e os objetos selecionados para serem ali exibidos, enquanto que no anexo haverá sinalizações e placas informativas, além de mobiliário para expor fotos e artefatos, televisão para reprodução de vídeos e um mostruário de artesanatos produzidos pela comunidade. A casa de artesanato, antiga escola da aldeia, também foi reformada com a troca de portas e janelas e reforma do telhado de telhas de barro. Atualmente o complexo cultural já passou por reformas estruturais e a execução da montagem do projeto expositivo e a inauguração estão previstas para primeiro semestre de 2020.

\footnotetext{
${ }^{14}$ Um dos programas que compõem o Projeto Básico Ambiental - Componente Indígena da hidrelétrica de Belo Monte.
} 
Figura 4: Mutirão de reforma do telhado de palha da casa de Leôncio Arara.

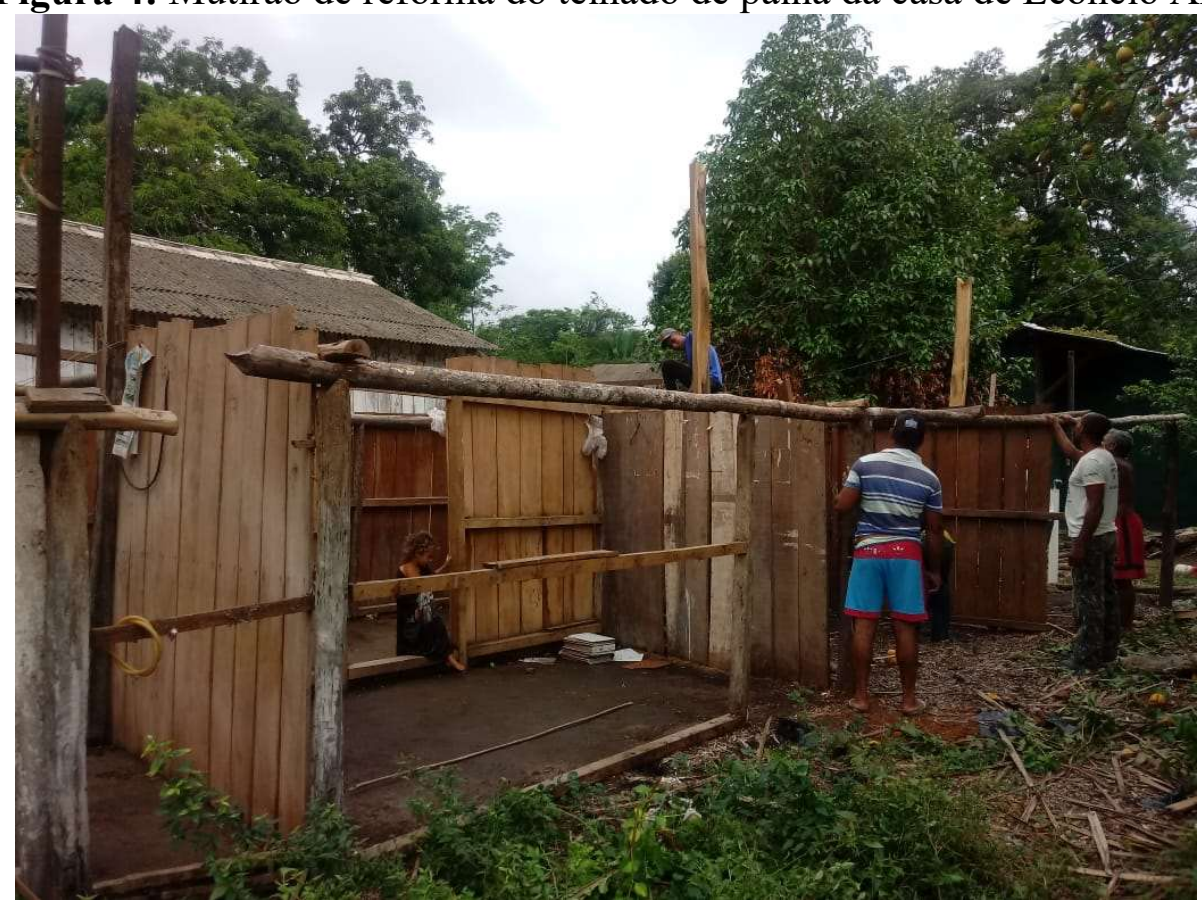

Foto: Lídice Juruna, 2019.

O processo de concepção da Casa de Memória resultou, além do compromisso assumido com Iracema, da participação de membros da comunidade nas atividades de formação em Patrimônio Cultural que ocorreram, sobretudo entre 2015 e 2017, como cursos, oficinas e intercâmbios com outros povos indígenas. Voltado para essa temática houve o curso com professores indígenas do Oiapoque cuja experiência por eles trazida com a constituição do Museu Kuahí foi fundamental para permitir o acesso dos Arara ao campo dos museus indígenas. Houve também a oficina de ocupação regional, voltado à pesquisa sobre a presença indígena na história da região da Volta Grande do Xingu oferecida pelo Programa de Gestão Territorial Indígena, também vinculado ao Projeto Básico Ambiental, que culminou na elaboração de uma apostila educativa (NASCIMENTO, 2017) e organizou informações históricas que irão compor uma linha do tempo como parte da exposição no anexo.

Houve ainda intercâmbios com a participação dos Arara, como o de professores indígenas que conheceram a experiência na Casa de Memória do Tronco Velho Pankararu (PE) e visitaram museus na cidade de Recife em 2015. Novos intercâmbios importantes ocorreram com os outros grupos Arara em 2018 - por ocasião do Encontro do povo Arara na aldeia Terra Wangã -, com a visita dos Arara da Volta Grande às TI Cachoeira Seca e TI Arara - ambas habitadas por outros grupos Arara - em 2017, e com a participação no ritual Jeipari, na TI Arara em 2015, que incluiu a presença de Leôncio, convidado junto de sua família. Nessas atividades participavam principalmente professores, jovens e lideranças dos Arara da Volta Grande. 
Figura 5: Leôncio Arara benzendo Wai Arara no seu terreiro, durante Encontro do

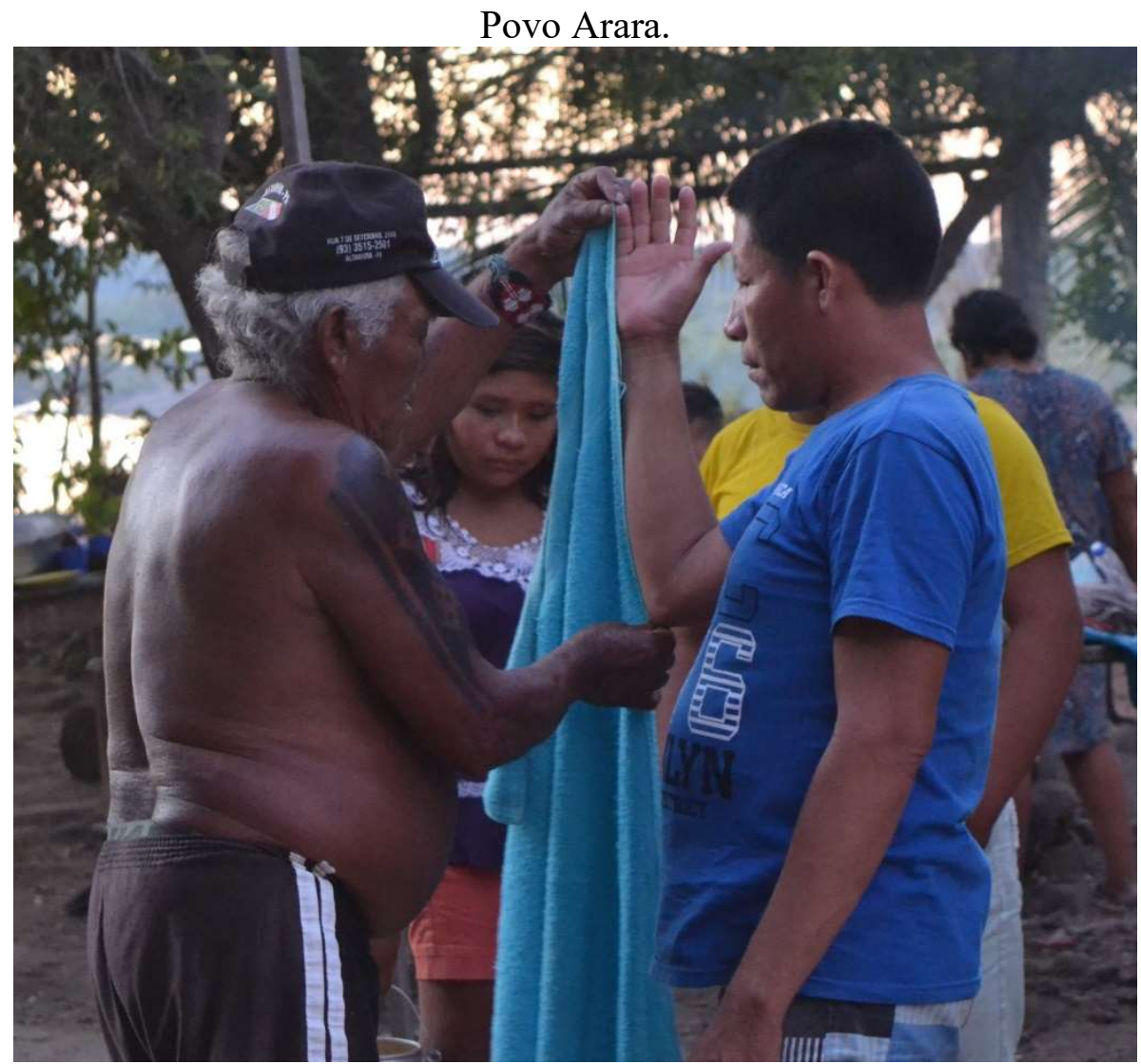

Foto: Renata Utsunomiya, 2017.

Como continuidade dessas atividades de formação em Patrimônio Cultural, participaram em 2017 de visitas aos seguintes museus: Museu do Índio no Rio de Janeiro; Museu de Arqueologia e Etnologia, na Universidade de São Paulo; Museu de Arte de São Paulo; Museu Histórico e Pedagógico Índia Vanuíre, em Tupã (SP) e o Museu Jandira Kaingang na Terra Indígena Vanuíre, em Arco Íris (SP). Essa última experiência, que ocorreu em dezembro de 2017 , no mês seguinte após o falecimento de Leôncio, representou o momento da sua inspiração definitiva em propor a fundação da Casa de Memória. Nessa visita, Dirce Kaingang e sua filha, Susilene Kaingang, apresentaram a aldeia e o museu aos Juruna e Arara presentes, esclarecendo que fora criado em homenagem à mãe de Dirce, que faleceu em 2016. O museu foi a casa de sua mãe, que foi mantida e preservada, com paredes de bambu e cobertura de sapé, e os seus objetos pessoais e artefatos produzidos encontram-se expostos no interior, como máquinas de costura, ferros de passar roupa, panelas de barro, entre outros. Segundo Dirce, o museu é o "coração da aldeia, onde está a nossa história", é "sagrado", pois possui peças sagradas em seu interior e, relembrando sua mãe, ressaltou a importância de pesquisar os mais velhos, pois esses são "dicionários" para abrir e usar. Por isso se deve buscar aprender, perguntar e aproveitar o máximo enquanto estão vivos, para quando estes se forem, ter "tudo na mão para se defender". Citou também sua importância para as crianças, para não perder essa memória, contada dentro de um museu. Além de ressaltar a importância do Museu 
Histórico e Pedagógico Índia Vanuíre, na cidade de Tupã (SP), do qual os Kaingang participaram na construção do acervo (GAZONI, 2014), Dirce afirmou a importância do museu indígena no território para a visita de não-indígenas, como estudantes, para estes verem o "museu do índio na nossa aldeia, com nossa história lá dentro". Susilene comentou que frequentemente perguntam-na porque o museu é uma "cabaninha". Ela costuma responder que tem orgulho de a casa ser dessa maneira, pois "lá está guardada a história da minha avó" a qual guardou sua memória porque sabia que assim estava "protegendo nós, sobrinhos, filhos, netos e bisnetos". Na roda de conversa que se seguiu à visita, Adalton refletiu sobre a memória de seu pai, curador e sábio, cuja luta foi de extrema importância para seu povo e expôs aos presentes as primeiras ideias sobre a preservação de sua memória e da concepção da casa como espaço museal. Toda essa discussão foi levada para a aldeia Terrã Wangã e motivou os Arara a realizar seu próprio museu. Como narra Lídice Juruna:

ter essa cultura o tempo todo viva, através do centro de memória, porque se não criar o centro de memória, vai ser esquecido, não vai ser trabalhado. É como se tudo que tivesse feito fosse em vão, e quando a gente fez o curso de museologia a gente viu a importância não só de guardar ele como uma pessoa relevante e essencial na construção do povo Arara, mas como os conhecimentos que ele trazia (LÍDICE JURUNA, 2019, p. 4).

Sensibilizados para a importância de preservação de seu patrimônio cultural, em suas dimensões materiais e imateriais, os Arara se mobilizaram para implementar o projeto da casa de memória. Joselha Arara, comentou que apesar de já desejarem manter a casa e a sua memória da passagem do ancião, foi respeitado um ano de luto, um "costume guardado" pelos Arara de não realizar festas, seguindo o que orientou o próprio Leôncio e, após esse período, iniciaram a busca de apoio para a realização da Casa de Memória.

$\mathrm{Na}$ primeira reunião de planejamento na aldeia, em novembro de 2018 , as perguntas orientadoras foram: o que é e qual o nome do espaço? Por que o construir? Neste momento se definiu o nome Casa de Memória Leôncio Arara, pois esse espaço seria dedicado à memória e ao conhecimento dele, com "tudo que se aprendeu" com o ancião, já com a intenção também de "levar para a escola", dado que este sempre se dedicou a transmitir saberes para os mais jovens e contava a sua história na escola, como relembra Joselha Arara. Alguns artefatos para compor o espaço museal foram citados - como bordunas, lanças e remos produzidos pelo ancião -, mas também os "remédios da floresta", como ele dizia, as plantas que ele conservava na cozinha de sua casa para prepará-los, e lá permanecem. Nesse primeiro momento, foi elaborado um plano de ação no qual se definiu as primeiras ações: a reforma da casa do ancião e a busca de doações dos artefatos produzidos por ele para compor o acervo, tarefa para a qual Joselha Arara foi escolhida como responsável. 


\section{A casa e seus objetos: interpretações do patrimônio cultural}

Nesta sessão, a partir do projeto e depoimentos, é descrita a Casa de Memória e cada parte desta, como a Casa de Leôncio e o Terreiro, e depois os objetos que compõem o acervo. Rememora-se falas do ancião e elucida-se percepções e interpretações sobre Patrimônio Cultural e sobre a memória de Leôncio do ponto de vista dos Arara.

A Casa de Leôncio Arara foi a primeira casa na margem direita do rio Xingu, na localidade que pertencia à sua tia-avó Tintim Arara, que fundou o que mais tarde viria a se chamar aldeia Terrã Wangã e, a partir dela, outras casas de seus descendentes foram se agrupando. Nas palavras do ancião: "meu tapirizinho tá bom demais, com ele eu não sinto a quentura porque não passa calor". Leôncio descrevia os saberes que envolvem a construção da casa, como as amarrações com cipó e o "japá”, trançado de palha para "colocar o capote" na cumieira do telhado, para iniciar a cobertura com palha da palmeira babaçu. Para ele:

Tem invenção, lá tem, tem 25 casas nova feita, mas como pra mim é invenção e eu sou de raiz, não tô me incomodando com invenção, quero saber da minha, porque eu debaixo da minha casa de palha, tapada mesmo, que é tapada de táuba, mas eu tô na minha cultura (LEÔNCIO ARARA, comunicação pessoal, 2015).

A casa era para ele uma resistência às mudanças com o contexto da hidrelétrica de Belo Monte, quando casas de alvenaria foram construídas entre 2016 e 2017, marcando também a importância da única habitação construída tradicionalmente que restou em sua aldeia.

Nos seus últimos anos de vida, Leôncio "ouvia logo cedo seu radinho na cozinha", onde costumava dormir e onde seus familiares vinham visitá-lo e tomar um café. Na cozinha permaneceram as sacolas com plantas, como ervas e "pedaços de pau" que ele utilizava para fazer os remédios. Segundo Joselha Arara, ele coletava esses materiais nas ilhas e na floresta e costumava fazer o remédio para ser consumido em seguida - não fazia garrafadas para guardar muito tempo, pois dizia que podia estragar. Segundo Leôncio, "tem que ter fé, você sabe que o que cura não é o benzimento, não é o remédio que você toma, o que cura é a fé" (VERTHIC, 2017b) e narrou o pajé, que se autointitulava curador, sobre seu trabalho:

A minha cultura é floresta, eu trabalho com as florestas, eu não acredito que doutor me trate, eu não acredito que tomando remédio na farmácia eu fique bom, (...) todo material meu é da floresta. Remédio, eu uso e trabalho na aldeia em três sentidos. Com a floresta eu trabalho pra remédio, o tipo de remédio, câncer, cisto, (...) esse aí eu trabalho com os remédios da floresta. Benzimento: vermelha, dor de dente, dor de cabeça, esses problemas, sabe? Cobrero essas coisas. (...) Batida de inseto, cobra, 
escorpião, aranha, arraia, todos esses insetos, trabalho com oração, entonce, aí é o que eu tenho, ainda tem umas 100 e tanto pessoa, (..) batido de cobra já foi 11 graças ao pai do céu nunca foi pra Altamira ou pra tomar outra coisa em outro canto. Vão lá comigo, tá batido de cobra, então vai conversar, com pouco tempo queria ir embora, posso embora? Vá. Livre da primeira palavra e pode ir (LEÔNCIO ARARA, comunicação pessoal, 2015).

Muitas estórias de curas são rememoradas entre os Arara, com alguns dos muitos pacientes curados na região de Altamira e indígenas de outras etnias como Juruna e Xikrin. Isso levou à decisão da aldeia Terrã Wangã de preservar suas plantas usadas para remédio.

No quarto da casa, onde dormia Iracema, ficavam produtos que vinham de Altamira que ele vendia para a comunidade, e era um local reservado que guardava também duas peças de cerâmica - artefatos arqueológicos - enterradas. A aldeia Terrã Wangã é um sítio arqueológico com manchas de "terra preta de índio" que apresenta "grande quantidade de material cerâmico e lítico" (VERTHIC, 2017b), os "cacos, panelas de barro e machadinhas", citados por Joselha Arara, que são encontrados em toda a aldeia. Ela conta que alguns chegaram a retirar uma urna funerária, um vaso cerâmico com ossos e um crânio dentro, e que foram advertidos pelo avô dizendo que iam "se assombrar". De acordo com os interlocutores, Leôncio costumava dizer que os Arara não tinham costume de enterrar seus mortos em panelas de cerâmica e atribuía a prática aos Asuriní15. Com sua casa construída em cima de duas urnas funerárias, ele ficou "protegendo ela ali" pois respeitava "quem estava lá e descansa" e por isso "não quebrou para não incomodar" e porque "a história não podia ser mudada", pois se tirasse "ninguém vai saber quem estava ali, não tem história para contar". Por essas razões, Leôncio não permitia aterrar ou reformar o piso da casa, que era de terra batida, para proteger esses artefatos.

Os dados coletados remetem à noção de que a casa, em conjunto com os objetos que lá estão e que ele confeccionava e lidava, é uma recordação dele. De forma unânime, os interlocutores relataram a importância de manter a casa em respeito à memória, para que mantenha a sua "lembrança", sua "aparência", pois qualquer mudança nesse espaço afetaria essa lembrança. Frases como "se mudar vai entrar em lugar desconhecido" e "quem conheceu, quando entra sente a presença do Seu Nego [Leôncio] ali dentro" reforçam essa noção. O objetivo, então, manifestado entre os Arara é de ir sempre reformando, deixando tudo do mesmo jeito para lembrar dele como se ele estivesse entre eles.

\footnotetext{
15 Tampouco os Asuriní dispõem de tal prática. Seus ritos funerários envolvem o enterro dentro de sua maloca tradicional, a tavyve, junto com pertences dos mortos, não incluindo, apesar da sofisticada produção cerâmica, o seu uso para tais finalidades (MÜLLER, 1993; SILVA, 2000). Não obstante, a margem direita do rio Xingu faz parte de uma vasta região de antiga ocupação de populações proto tupi-guarani que, entre outras práticas, utilizavam cerâmica para o enterro de seus mortos (ALMEIDA; GARCIA, 2008; ALMEIDA; NEVES, 2015). A atribuição desse costume aos Asuriní pode ser explicada pelo fato desse lado da margem do Xingu ter sido designado como pertencente a essa população desde meados do séc. XIX (MÜLLER, 1993).
} 
Assim como a casa, a presença de Leôncio também é lembrada no terreiro, localizado ao lado de sua casa, entre esta e a antiga casa de Adalton Arara. Próximo à margem do rio Xingu e do principal porto da aldeia, o espaço era o local em que todos que chegavam se deparavam. Como o ancião ficava mais no terreiro que dentro da própria casa, os recém-chegados logo se encontravam com ele. No local de chão de terra pedregoso, as pessoas costumavam ficar sentadas na sombra dos pés de tamarindo e laranja, onde havia também um canteiro com temperos e plantas medicinais. Ao lado, alguns metros adentrando a aldeia, há um pé de jambo, onde Leôncio também gostava de confeccionar artefatos de madeira e cipó. Todos eram acostumados a encontrar ele lá no terreiro e lá se tinha os bancos, mesa, tinha o fogareiro dele, que era pra fazer seu assado, tinha lá o pilão, tinha um lugar onde ele benzia as pessoas.

A mesa e os bancos foram retirados do local após a mudança de Iracema, mas as pedras do fogareiro permanecem no local, que foi recentemente "capinado" com a intenção de ser mantido sempre limpo. Os homens, quando retornavam da caça, costumavam "tirar o couro" embaixo do pé de tamarindo e, em sua mesa de tábuas de madeira, Leôncio preparava e salgava carne de caça ou peixe. Além de preparar, ali a carne era assada e servida para toda a família que circulava no terreiro, "de mamando a caducando" como ele dizia. Lá havia também um pilão, o qual está guardado e também fará parte da exposição, que pertencia anteriormente à cunhada e já falecida irmã de Iracema, Alexandrina dos Passos (PATRÍCIO, 2009), utilizado para socar grãos e para preparar o óleo de babaçu que o casal Iracema e Leôncio faziam. Sentado na cadeira, passava o dia recebendo visitas, contando estórias, aconselhando familiares, cuidando de seus netos. Todos passavam por lá indo ou voltando de seus afazeres: as mulheres lavando roupas e louças, famílias indo se banhar, os homens voltando da caça ou pesca, etc. Pela manhã e no fim da tarde eram os momentos que chegava mais gente atrás de remédios "da floresta" ou de benzimentos e orações. Muitos benzimentos aconteciam diariamente no terreiro, principalmente para "peito aberto" ou "peito mocado" no qual utilizava uma toalha rosa que foi enterrada junto com ele. As dores na região do peito são esforços que se "faz com os braços e com o peito que abre, e dói, e se abrir demais e não cuidar a pessoa morre". São muito comuns pois "a vida do índio é carregar peso" como descreveu Lídice Juruna (2019).

Nas conversas sobre os trabalhos de cura de Leôncio, o "cordão de reza" foi um dos objetos lembrados para compor o acervo da Casa de Memória, porém não foi encontrado nenhum para a exposição. Era um cordão que a pessoa usava até perdê-lo ou ser curada, como descreve Joselha Arara:

Era um [cordão] de reza que ele rezava, por exemplo, pra quebranto, quando o quebranto na criança estava muito forte, aí ele fazia o cordão, colocava no pescoço da criança, (...) ele benzia já tirando do cordão pra criança não ficar tão maltratada assim, porque o quebranto ele dá diarreia, dá vômito, ele dá tudo isso, 
esses sintomas. Aí ele fazia pra peito aberto, pra dor de dente, pra um bocado de reza. (JOSELHA ARARA, 2019, p.02).

Figura 6: Terreiro da casa de Leôncio e Iracema

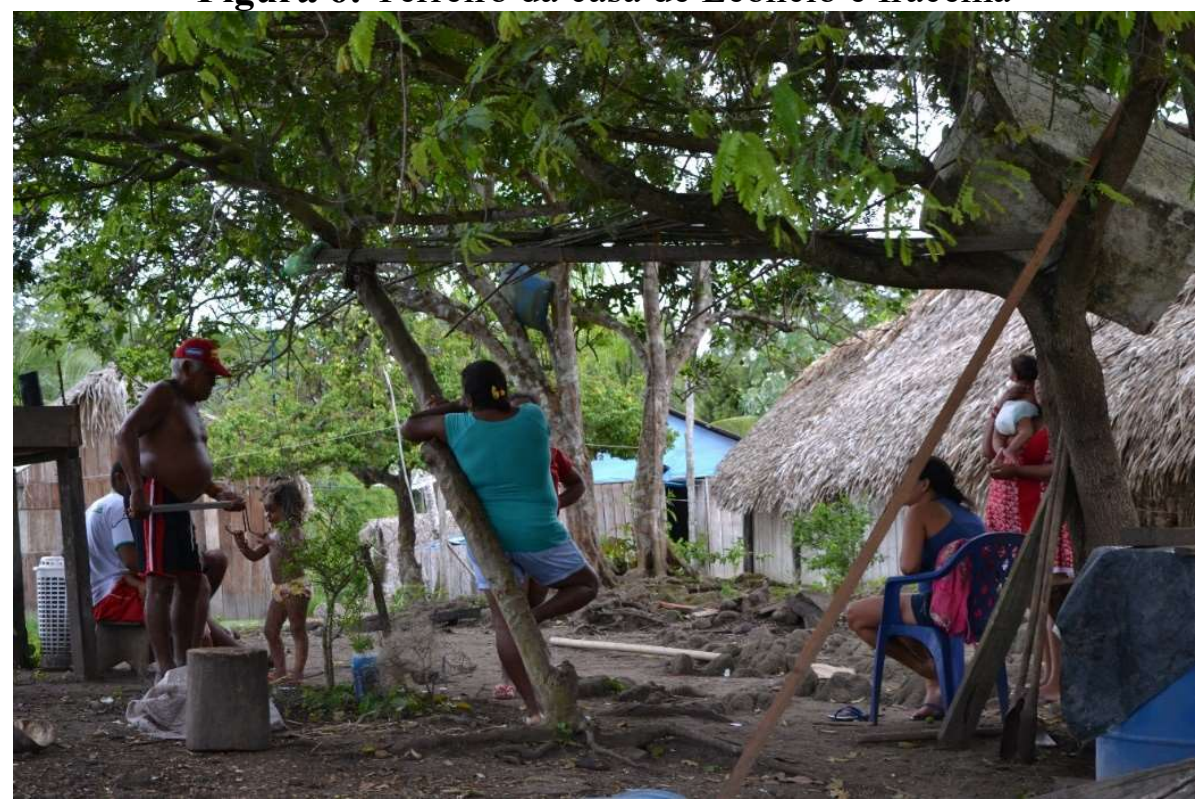

Foto: Renata Utsunomiya, 2015.

Assim como a casa, o terreiro também guarda muitas lembranças do ancião, por isso muitos evitam ficar no espaço, pois é considerado como um ambiente "muito forte". Às vezes Iracema com alguns filhos e netos visitam o local, porém logo se emocionam e choram. Essa prática tem sido evitada, pois acreditam que isso perturbaria o caminho postmortem do falecido, causando sofrimento a ele. Por essa importância que tem o terreiro da casa de Leôncio, como centro das relações sociais da comunidade quando este era vivo, o espaço foi incluindo como parte da Casa de Memória e está prevista no projeto executivo uma sinalização específica para ele.

Os artefatos que produzia no terreiro estarão expostos tanto na Casa de Leôncio quanto no Anexo, e abrangem remos, bordunas e lanças. Reconhecido como o "maior artesão que tinha nessa aldeia", demonstrava também muita vontade e prazer de ensinar os mais jovens, como comenta a professora Lídice Juruna. O ancião relembrava a importância desses artefatos de caça e pesca na fala dos "antigos": "os velhos mesmo, Pirá, Arini que recomendava nunca deixar de fazer o arco, a flecha e a borduna porque era a arma do índio" (Verthic, 2017a). Os artefatos também retomam lembranças das pescarias com a mãe Firma Arara quando era pequeno, como no caso do arco e flecha que a geração dos filhos de Leôncio também chegou a usar quando eram crianças:

Dedicação da minha mãe, nós usava assim, fazia aqueles arco e mandava nós flechar peixe, nós começamos a flechar peixinho assim na beira da água e daí ia fazendo 
o grande e matando peixe [Leôncio Arara] (VERTHIC, 2017a).

Leôncio fazia remos para uso e chegou a vender quando era jovem. Nos últimos anos fazia também remos em miniatura que costumava presentear crianças, parentes e amigos, mas dificilmente vendia. Como ele disse para Joselha Arara: "esse daqui quando eu morrer fica de lembrança pra tu". O último remo que confeccionou e chegou a ser vendido para uma loja em São Paulo acabou retornando como doação para o acervo da Casa de Memória, após o falecimento do ancião e a visita de representantes Arara em 2017.

Figura 7: Leôncio Arara e o ultimo remo produzido, parte do acervo da Casa de Memória

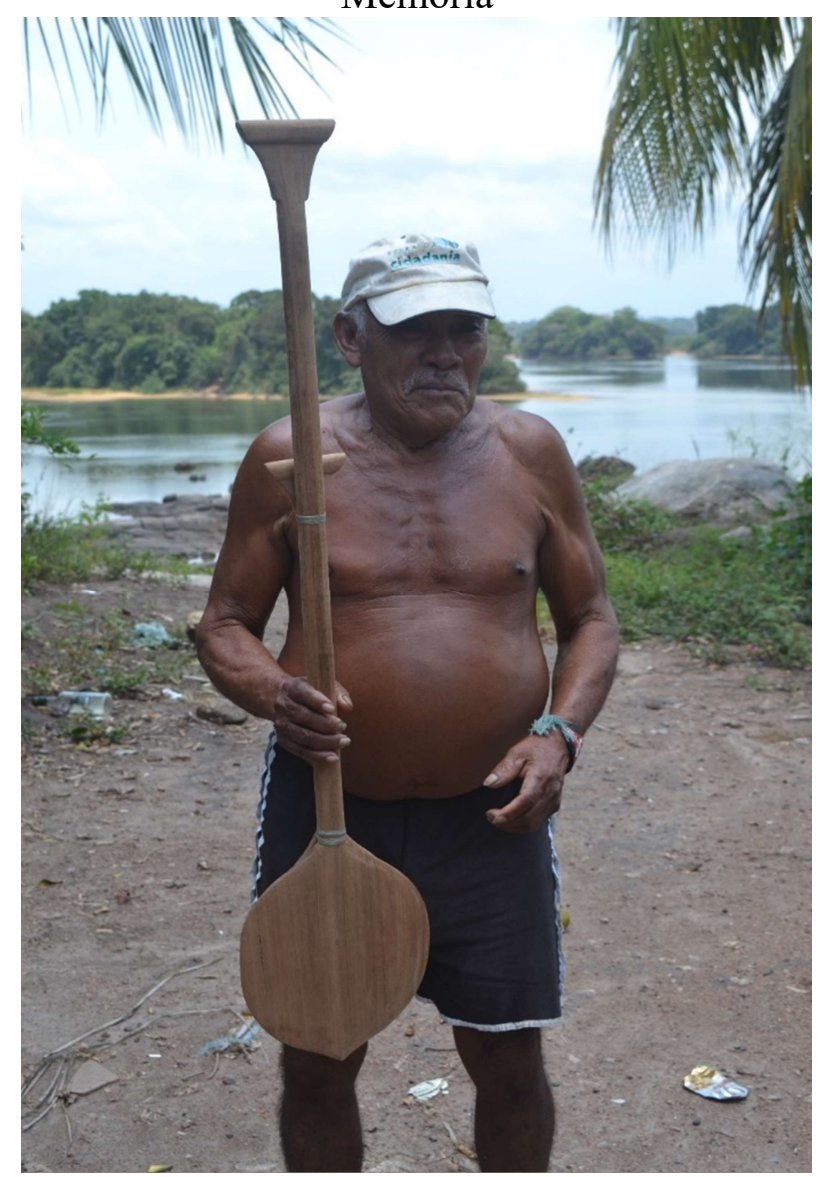

Foto: Renata Utsunomiya, 2017.

As bordunas também eram produzidas em tamanho normal e em miniaturas para enfeite e para presentear. Arlindo Arara comenta que ganhara uma borduna, artefato que era, e é, utilizado para abater animais como o porcão (queixada), sobretudo no período da cheia do rio Xingu, quando estes atravessam o rio em grandes bandos. Utilizando apenas facão para moldar e caco de vidro para dar o acabamento, Leôncio produziu muitas bordunas e, junto com o remo, compõem os artefatos mais numerosos do acervo - muitos homens da aldeia aprenderam e continuam a fazer esses artefatos. Apesar de não utilizarem mais para a pesca ou caça nos dias atuais, o arco e a flecha também são 
confeccionados e utilizados em momentos de dança, jogos estudantis ou de realização de manifestação para reivindicações de direitos (VERTHIC, $2017 a$ ).

Leôncio confeccionava artefatos de palha, geralmente da folha de palmeira babaçu, como coufo, paruá ou pacutu, pêra, esteira e abano. Apesar de não comporem a Casa de Memória como objetos para exposição, estão presentes como registros fotográficos de uma atividade, em parceria com a escola, em que o ancião ensinou esses artefatos para as crianças em seu terreiro. Segundo o ancião, "O índio fazia tudo assim, ele não tinha nada feito, mas na hora que ele arrumava qualquer coisa, ele fazia qualquer coisa pra trazer tudo de lá" (VERTHIC, 2017b). Pois apenas com um facão andando na floresta é possível tecer rapidamente cestos cargueiros descartáveis, como o paruá e a pêra, com a folha de açaí ou babaçu e assim ele "carregava tudo do mato" seja uma caça abatida ou produtos extrativistas e da roça.

Os artefatos de cipó também eram produzidos pelo artesão - como a vassoura e o paneiro, tipo de cesto cargueiro. O cipó timbó ou titica era descrito por ele como de grande utilidade e ainda é utilizado pelos Arara na amarração das casas ou amarrado para carregar caças abatidas, o chamado "vira-mundo". Durante as descrições desses artefatos, o ancião narrava as transformações nos artefatos usados no dia-a-dia e a dificuldade do interesse dos mais jovens "por causa da elevação, por causa do movimento, você repare que até o paneiro saiu da moda, por caso de saco, agora só querem carregar saco" (VERTHIC, 2017a).

Os artefatos de caça e pesca e os feitos com cipó e palha remetem a práticas no modo de vida dos Arara, tanto nos saberes que envolvem coleta da matéria-prima e a confecção, quanto seus usos que, apesar das mudanças históricas narradas pelo ancião, persistem enquanto objetos importantes para a memória e afirmação da identidade indígena.

Figura 8: Leôncio ensinando artefatos de palha para as crianças.

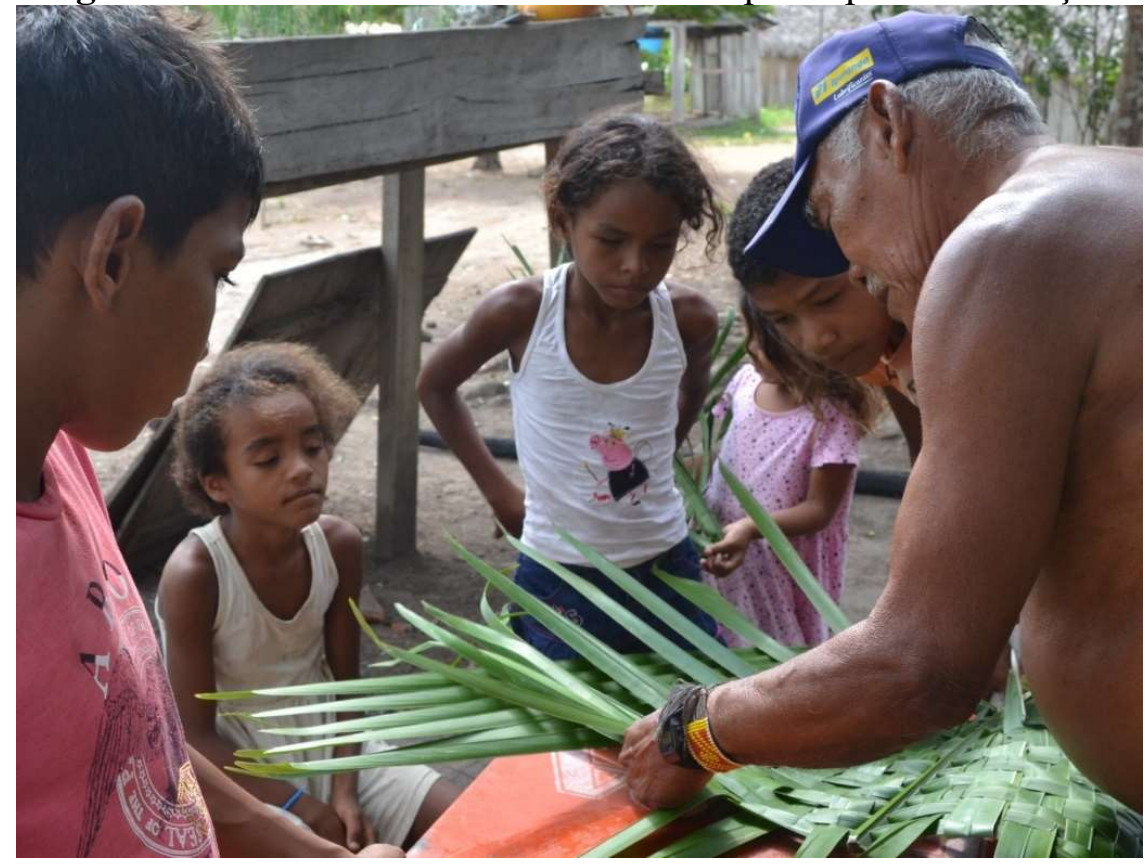

Foto: Renata Utsunomiya, 2016. 
Alguns objetos da Casa de Memória, como a pele de onça e a faca de seringa, retratam também outros antigos ofícios do ancião. Leôncio foi "caçador de gato", ou "gateiro", como são chamados os que caçavam pele de onças, gatos maracajás, lontras e ariranhas da região para comercialização até quando esta foi proibida (VERTHIC, 2018). A faca de seringa também relembra outra importante atividade econômica no qual o ancião, na esteira do pai, se engajou.

Esses artefatos remetem aos ciclos econômicos que perpassaram o povo Arara e, apesar do histórico já descrito dos resultados dessas atividades nos povos indígenas da região, fazem parte da história deste povo. Leôncio narrava sobre as práticas desses ofícios, onde percorria a Volta Grande do Xingu entre ilhas e terra firme com sua canoa e remo, além de percorrer todo o território durante a época que era "gateiro" (LEÔNCIO ARARA, comunicação pessoal, 2016).

Também estará exposto na Casa de Memória o cocar que o ancião utilizava nas festas e reuniões, que foi um presente do filho Adalton a ele. Este cocar foi produzido por um artesão Juruna da aldeia Boa Vista, da Área Indígena Juruna do km 17, comunidade de onde veio Lídice Juruna.

No anexo da Casa de Memória, serão abordados também aspectos do Patrimônio Cultural Imaterial dos Arara, visto que o ancião contava, além da história de seu povo, estórias que refletem aspectos da cosmologia Arara, estórias de cura, e também sobre a pajelança que sua mãe fazia:

Pajelança era assim pra cura e saber de movimento não sabe? Cuma era que tava passando, os movimentos, era tempo dos índios bravo não sabe? Se aqueles índios tavam por perto, se tava, tinha alguém, algum projeto de mexer com alguém daquela família. (LEÔNCIO ARARA, comunicação pessoal, 2016).

Os Arara "conhecem os segredos das 'matas', do rio, vivem do que elas oferecem e, numa relação intrínseca, alimentam o corpo e o espírito" e, assim, o rio, as "matas" e as ilhas tem "suas próprias entidades" (PATRÍCIO 2006, p. 80; 2009). Como dizia o ancião "o rio fala, ele conversa" e "para entrar na mata é preciso pedir licença" (LEÔNCIO ARARA, comunicação pessoal, 2016). Como descreve Patrício:

Diante disso, a compreensão que Leôncio Arara apresenta em seu discurso, (...) remete à ordem existente nos fenômenos sociais significativos em seu grupo social. Ou seja, existe uma ordem mínima das coisas da vida relativa às crenças, à visão de mundo, ao ambiente em que vivem e se reflete no cotidiano do trabalho da pesca, caça, no cuidado com as crianças, do nascimento à morte. A comunicação que estabelecem com o meio ambiente circunscrito ao território de uso ou extensivo à região mais ampla alimenta esse sistema simbólico (PATRICIO, 2009, p. 76). 
Entre estas entidades, narradas como "espíritos" pelo ancião, estão o "Bujaleco", a "Mãe d'água" e o "Jurupari", também chamado "Pai da mata". O Pai da mata é um espírito que guarda a floresta, o guardião da floresta, dos animais e tudo aquilo que pertence à floresta. Já a Mãe d'água é quem cuida da água e tudo aquilo que fica na água. Leôncio narrava que "as pessoas tem que saber andar no rio como também na mata, se não souber se comportar frente à água a pessoa pode ser 'batida' pela mãe d'água, é arriscado a pegar" (PATRICIO, 2009, p. 77). Os espíritos guardiões podem, portanto, punir aqueles que desrespeitam "as matas" e o rio e, assim, ser "batido" por eles. Essas punições ocorrem quando há desrespeito de interdições, como quando se caça demais e no lugar errado e acarreta o encostamento daquele espírito na pessoa, causando febre, dor de cabeça. Esse assédio pode ser revertido por meio de banho de ervas e benzimentos.

O livro "O Pai da Mata" (Senador José Porfírio, 2015), foi elaborado pelos Arara e conta a estória no qual Arlindo Arara, durante uma caçada, chegou a ver o "Jurupari", ficou doente e foi curado com benzimentos feitos por Leôncio. Segundo Adalton, embora Arlindo não estivesse desrespeitando naquele momento, ele estava em um caminho de bastante caça e acabou vendo o Pai da Mata. Como esse é um espírito de energia muito grande, só dele passar perto da pessoa ela fica abalada, abatida, deixando a pessoa baqueada. Esse livro irá compor também o acervo da Casa de Memória e há um vasto acervo de vídeos e áudios de Leôncio narrando a história de seu povo, e esses diferentes aspectos do patrimônio cultural imaterial dos Arara ${ }^{16}$ mencionados acima, registrados entre 2014 e 2017.

Além dos vídeos que comporão o anexo da Casa de Memória, haverá fotos do cotidiano do ancião e da comunidade, a produção de artefatos, e também festas e brincadeiras realizadas pela escola da aldeia. O festejo de São Francisco das Chagas, iniciado por Francisco Lopreu, tio de Leôncio, e realizado há mais de 25 anos no dia 4 de outubro, também foi registrado em um documentário em 2017. Outros eventos organizados pela aldeia, como o Dia do Índio, ou mobilizados pela escola, como o São João, sempre foram incentivados por Leôncio, que contribuía com a produção da bebida fermentada amuru, que pode ser feita com cará, macaxeira, inajá, olho da inajá e fruto da inajá.

\footnotetext{
${ }^{16}$ Esse acervo de vídeos e áudios será posteriormente selecionado e editado para exibição no espaço do anexo da Casa de Memória. Videoastas indígenas em formação, até então, pelo Vídeo nas Aldeias (com oficinas já ocorridas em 2016, 2017 e 2018) trabalharão sobre esses materiais brutos nas próximas oficinas que fazem parte das atividades de formação em Patrimônio Cultural. As filmagens englobam: intercâmbios culturais (imagens de Josivan Arara, Dhemerson Arara, Kamikia Kisedje, Rinaldo Santana, Renan Arnault e Renata Utsunomiya); entrevistas sobre história regional (imagens de Josivan Arara e Dhemerson Arara e entrevista realizada por Hilton S. Nascimento); vídeos brutos do documentário "A Última Volta do Xingu" (imagens de Kamikia Kisedje e entrevistas por Wallace Nogueira) e filmagens realizadas durante diagnósticos e outras atividades de campo por Hilton S. Nascimento, Rinaldo Santana e Renata Utsunomiya. Documentários realizados incluem o curta-metragem "Festejo de São Francisco" (Hilton S. Nascimento) e "A Última Volta do Xingu” (Kamikia Kisedje e Wallace Nogueira).
} 


\section{Casa de Memória Leôncio Arara: passado, presente e futuro}

A partir das informações aqui reunidas acerca do processo de implantação da Casa de Memória, é possível identificar alguns aspectos que nortearam sua criação e organização. O primeiro e mais importante é seu objetivo: perpetuar a memória e a presença de Leôncio Arara. Essa preocupação se justifica aos olhos de seus parentes, devido ao papel que esse antigo líder exerceu no processo de formação dos Arara, com sua luta política, conhecimento histórico, curas e aconselhamentos. Essa preocupação se materializa no desejo de manter a casa de Leôncio em sua condição tradicional, de quando o ancião estava vivo e morava com sua esposa. Além do acúmulo do acervo produzido sobre esse importante personagem, esse cuidado explica a opção por deslocar a parte do acervo que não pertencia ao dia a dia da casa de Leôncio, fotos, depoimentos, livros, vídeos, para o anexo. Como bem sintetizou Adalton,

(...) hoje em dia a gente tem, com a construção do museu em si, a gente formou como se fosse um complexo. A casa dele é exclusivamente para as coisas dele. Para expor tudo aquilo que ele construiu durante anos, naquilo que ele acreditava, né. A casa é dele. Aí tem um anexo que é para expor alguma coisa dele, material que foram feitos, que ele tem, depoimento de algumas pessoas que ele possa ter curado, que ele era pajé. Pessoas contando o que ele fez e algumas fotos dele e lembranças, alguns vídeos também. $\mathrm{E}$ nesse anexo também vamos começar a expor algumas outras coisas. Eu já acho que coisas de nosso dia a dia, que a gente faz, fazia, né. A gente vai expor também a nossa história. Essa parte é a parte que vai ficar do povo Arara. A casa dele é para o expor as coisas dele. Para deixar ali a memória dele aí presente. (ADALTON ARARA, 2019, p. 3).

Frente a um contexto de grandes transformações decorrentes da construção da hidrelétrica de Belo Monte que trouxe mudanças em seu modo de vida, a casa de Leôncio Arara está em vias de se transformar em um espaço que remete ao passado recente desse povo. Por ser o ponto que deu origem à aldeia e no qual todos orbitavam, sendo simultaneamente local de passagem, refeição coletiva, tratamento de caça, espaço de cura, confecção de artefatos e contação de histórias, o projeto se esforça por transformar esse epicentro da aldeia em um espaço museal, em um trabalho de tornar objetivo as relações que ali foram tecidas. Não é por acaso que, por ser a última casa tradicional Arara da aldeia Terrã Wangã, ela foi transformada em objeto expositivo em si, condensando as origens dos Arara do VGX, seu antigo modo de vida, sua cultura material, por meio dos objetos, e imaterial, com o acervo contido no anexo. A casa de Leôncio e seus anexos materializam um complexo esforço comunitário de autorrepresentação: 
Tem uma outra coisa que é o anexo do anexo, que já é uma casa para produção de artesanato. É como um efeito, o passado, o presente e o futuro. O passado é a casa dele, que é para contar nossa história de quem iniciou. O presente pode ser o museu lá, o anexo, porque a gente vai expor aquilo que a gente tá fazendo, também um pouco do que a gente fez. Vai ficar um tudo. Do passado para o presente aquilo ali, que é o que a gente tá fazendo agora e o que a gente fez lá atrás e até o que ele representa pra gente. E o anexo/casa de artesanato é a produção do futuro. Que é a produção dos materiais que vão nos representar no futuro próximo. Ali é que vai ser dada continuidade de nossa cultura. A produção de nossos materiais culturais. Ali vai ser uma sala de ensinamento, que eu acho que é o melhor nome. É o futuro que ali começa, porque você está incentivando as pessoas a levarem aquilo adiante. Isso é que representa para gente. (ADALTON ARARA, 2019, p. 4).

Um complemento necessário e explícito a todo esse projeto é a preocupação pedagógica de ensinar uma história de forma correta e verídica para dois públicos: um interno ao povo e outro externo a ele. $\mathrm{O}$ público interno seriam os jovens que não tiveram a oportunidade de conviver e aprender com Leôncio as histórias e o modo de vida Arara. Uma vez que estiver concluído, a presença do ancião ficará "mais forte" e será mais fácil ensiná-los (JOSELHA ARARA, 2019, p. 13-14). O externo, para os visitantes e não-indígenas, que ela ensine sobre Leôncio e o povo Arara. Segundo Adalton, o objetivo é menos de passar uma história positiva sobre eles, mas verídica. E principalmente desmistificar a noção de que suas vidas são fáceis.

A gente espera que ele fique realmente lá. As nossas expectativas é que as pessoas que vem, às vezes, visitar ou então estão de passagem, e realmente estão interessados em saber um pouco da nossa história. Que ele passe realmente essa informação clara, como foi, como é a nossa história do passado, como é a história do meu pai. Que ele esclareça isso pras pessoas saírem sabendo quem ele era também, sabendo quem era nosso povo. É isso que a gente espera realmente, que passe realmente a história, a nossa história realmente, que a pessoa que vir lá, levar uma resposta positiva, não só positiva, mas também verídica do nosso povo.

[Entrevistador] Como assim não apenas positiva, mas também verídica?

Eu acho que é verídica. Às vezes, (...) a pessoa que está lá que acha que a nossa vida é boa, é fácil. Isso é um lado que as pessoas pensam, que para nós é negativo. $\mathrm{E}$ ele leva essa história e muitos vem acham que é isso mesmo que está acontecendo (...). Para nós isso é negativo. "Ah a vida dos índios é tão boa, porque índio 
não faz nada, índio não faz aquilo" e não é isso. Acha que a nossa vida é boa, mas pra ele que visita, mas não é. (...) o que a gente quer passar é que a gente tem o que tem não é porque é dado para nós de graça, teve uma luta ali por cima daquilo, é direito nosso. É essa impressão que a gente tem que passar, se hoje a gente tem o que tem a gente está nesse patamar, brigando, melhorou saúde, educação, não foi dado de mão beijada, foi reconhecido nossos direitos. É o que a nossa história vai contar lá através do fortalecimento. Que o pessoal hoje, "o povo não é índio", e a nossa história vai fortalecer isso, o museu vai fortalecer isso, contando lá no passado era desse jeito. Se a gente está desse jeito é que a gente batalhou pra ainda se manter essa cultura. Porque tem outros povos que até se extinguiram, e hoje em dia nossa briga é de a gente sempre se fortalecer, sempre nos fortalecer. E esse museu é isso (...). (ADALTON ARARA, 2019, p. 8).

A afirmação da "contar nossa história" de forma "verídica" reafirma a importância da iniciativa museológica sob o protagonismo indígena. Cada vez mais os museus etnológicos vêm sendo repensados a partir dessa emergência dos povos originários como sujeitos, e não mais como apenas informantes e produtores de artefatos para coleções etnográficas. Dessa forma, que perdurou até metade do século $X X$, os etnólogos se esforçavam em "recolher elementos da produção material de pequenas sociedades que corriam o risco de se extinguirem" (GRUPIONI, 2008, p. 21). Nesse processo:

Evidentemente, muitos grupos deixaram de existir enquanto totalidades sociológicas, mas os que sobreviveram, continuam afirmando-se enquanto povos, e é para alguns deles que as coleções depositadas em museus começam a ganhar sentido, seja porque, expostas em museus e em exposições, revestem-se de uma importância que lhes permite sentir orgulho de suas produções materiais e de suas próprias identidades indígenas, comumente sujeitas a preconceitos e estigmas; seja porque, nestas produções, identificam matrizes culturais de práticas e valores que foram perdidas ou abandonadas ao longo do tempo, e para as quais lançam tentativas de recuperação e de resgate, em processos de reafirmação étnica. (GRUPIONI, 2008, p. 27).

Além do crescente interesse dos povos indígenas em revisitar coleções de seus antepassados, Grupioni (2008, p. 28) também cita o processo de apropriação da instituição museu por parte dos povos indígenas: 
Em anos recentes, alguns povos indígenas estão se apropriando de instituições típicas da sociedade envolvente para reforçar laços internos e valorizar suas práticas culturais, criando novos espaços de comunicação interna e com um público maior. É o caso da constituição de centros culturais indígenas e de museus indígenas, idealizados, construídos e apropriados por estes povos, não como meras cópias de instituições ocidentais, mas de acordo com suas lógicas próprias e mecanismos específicos de controle.

Atualmente há um incremento no número de museus indígenas e regionais no mundo e entre exemplos dessas iniciativas há o Museu Kuahí, no Oiapoque, no Amapá, (VIDAL, 2008), o Museu Jandira Kaingang e a Casa de Memória do Tronco Velho Pankararu (GOMES, 2014) já citados acima. Mas que facilmente encontram-se outros exemplos, entre os quais, alguns do mais antigos aqui no Brasil são o Museu Magüta (ROCA, 2015) e o Museu dos Kanindé (GOMES, 2014). Por essa ótica, o museu pode ser pensado como "um espaço vivo, de resgate da memória e de orgulho e afirmação de suas identidades étnicas" e há maiores esforços de indígenas - que atualmente viajam, fazem intercâmbios e conhecem outras iniciativas museológicas - antropólogos, artistas e curadores, em "valorizar as artes indígenas a partir de novas atitudes estéticas e participativas". Com isso, os indígenas estão descobrindo que o museu pode ser um espaço "importante em suas lutas de autodeterminação" (GRUPIONI, 2008, p.29; VIDAL, 2008, p.109).

A Casa de Memória Leôncio Arara é mais um caso inserido nesse atual contexto crescente de ações museológicas com protagonismo indígena. Considerando o processo tardio de reconhecimento da identidade indígena e da demarcação da TI Arara da Volta Grande do Xingu, há uma histórica e presente estigmatização contra povos indígenas como os Arara. Esse quadro agrava-se no atual contexto de rápidas transformações socioculturais e no seu modo de vida. Nesse sentido, a luta pela reafirmação étnica é colocada como de extrema importância e a Casa de Memória é central nesse processo. Não apenas tem importância de demonstrar a trajetória histórica dos Arara para visitantes, quanto para o "fortalecimento cultural", como citam os indígenas, ou seja, a permanência da transmissão dos saberes para as próximas gerações, como era preconizado pelo ancião. Fazendo um paralelo com as falas de Dirce e Susilene Kaingang, ter o "dicionário" para abrir e usar, mas também para "se defender" pois os anciões guardam sua memória para "proteção" de seus descendentes. As preocupações de Leôncio em não mexer e preservar sua casa e as cerâmicas refletem também essa proteção, para que a história permaneça e possa ser contada. 


\section{Considerações Finais}

À guisa de conclusão, é possível perceber que há uma associação dos membros da Terrã Wangã à casa e o personagem de Leôncio Arara. Não só os entrevistados, mas também muito moradores da aldeia reconhecem essa associação. A preservação de sua casa, seria uma das formas de mantê-lo vivo, tanto sua presença, quanto as lembranças que eles têm dele e de também ajudar os mais novos a conhecerem sua luta pelo povo Arara.

Nesse sentido, a casa e os objetos expositivos não são apenas objetos coletados produtos de relações sociais, mas também "vetores de novas possibilidades de relações" (GRUPIONI, 2008, p. 29) recolocando o papel do museu indígena como importante não apenas para o registro do passado, mas também para a "fortalecimento cultural" no futuro.

Embora Joselha Arara tenha indicado a necessidade de esquecimento dos mortos para ajudar no processo de luto, a construção da Casa de Memória não representaria uma ameaça, por despertar saudade e sofrimento, a eles. Mas seria um importante instrumento de transmissão, especialmente para as crianças que não tiveram oportunidade de conviver com Leôncio reconhecer a importância desse líder para a vida dos Arara. Curiosamente, a casa de Seu Nego é a última casa no modo tradicional Arara da aldeia Terrã Wangã no contexto que quase todos os moradores atualmente dispõem de casas de alvenaria. De certa forma, ela é sim um monumento ao modo de habitação antigo, mas não só. Com a iniciativa da Casa de Memória, ele está se tornando a casa do que conta o passado do povo Arara.

Há, entre eles, uma associação entre a cultura do índio e as coisas materiais que eles fazem. Os entrevistados falam com recorrência das coisas que ele fazia e que vão ficar na casa dele. Isso parece ser uma percepção generalizada, pois outros interlocutores também se referem a objetos e artefatos que fazem, assim como a culinária e as bebidas tradicionais, como algo feito "na cultura". Essa concepção de cultura enquanto uma cultura materializada também se encontra na citação que Leôncio faz de seus antepassados, "É a arma do índio. Os velhos mesmo, Pirá, Arini que recomendava nunca deixar de fazer o arco, a flecha e a borduna porque era a arma do índio" (Verthic, 2017a).

Os artefatos remetem tanto à memória de Leôncio Arara, como também a elementos importantes da história de seu povo, como a faca de seringa e o couro de onça que estavam ligadas a importantes atividades econômicas da região nas quais o ancião e seus parentes se envolveram.

A reflexão acerca das percepções dos Arara da Volta Grande sobre o patrimônio cultural material e imaterial remete à noção de cultura e identidade:

Há dois modos básicos de entender a noção de cultura e de identidade. O primeiro, a que poderíamos chamar, por simples conveniência, de platônico, percebe a identidade e a cultura como coisas. A identidade consistiria em, pelo 
menos como um horizonte almejado, o de ser idêntico a um modelo, e suporia assim uma essência, e a cultura seria um conjunto de itens, regras, valores, posições etc. previamente dados. Como alternativa a essa perspectiva, pode-se entender a identidade como sendo simplesmente a percepção de uma continuidade, de um processo, de um fluxo: em suma, uma memória. A cultura não seria, nessa visão, um conjunto de traços dados e sim a possibilidade de gerá-los em sistemas perpetuamente cambiantes. (CARNEIRO DA CUNHA, 2012, p. 120, Grifo do autor).

Considerados fora da rota dos "padrões indígenas tradicionais" como resultado de sua trajetória histórica (PATRícIO, 2006), os Arara passaram por longos períodos de apagamento da identidade indígena, ou "ocultação dessa identidade" como cita Carneiro da Cunha (2012, p. 109), talvez pela constante noção de cultura no sentido "platônico" invocado pela sociedade que os circunda, ou por setores com interesse na negação dessa identidade, levando-os a interpretação de não serem "idênticos a um modelo". Porém, o debate atual da identidade étnica como "exclusivamente função da autoidentificação e da identificação pela sociedade envolvente" traz à tona a afirmação étnica desses grupos indígenas chamados de "ressurgentes" ou "emergentes".

Tal contexto se assemelha aos povos indígenas localizados no nordeste brasileiro em que a "interferência nas culturas tradicionais atingiu também a religião, os costumes matrimoniais, a organização política, a tecnologia, os hábitos alimentares, estes já afetados pela depauperização dos territórios de caça e pesca" obviamente com devidas diferenças regionais. Diante desses cenários:

A resistência indígena a essa interferência manifestou-se no apego a alguns traços culturais que, enfatizados, preservavam a identidade do grupo. Esse é um processo recorrente na afirmação étnica: a seleção de alguns símbolos que garantem, diante das perdas culturais, a continuidade e a singularidade do grupo. Assim, quase todas as comunidades indígenas do Nordeste preservaram o ritual do ouri-curi ou toré - a que ninguém, a não ser os índios, tem acesso - enquanto muitas outras tradições foram abandonadas. (CARNEIRO DA CUNHA, 2012, p. 107).

Arruti (1997, p.30) também cita esses grupos: "no caso dos remanescentes indígenas, encontrou respaldo em um estereótipo definido a partir de modelos etnológicos amplamente difundidos que encontraram no Toré a sua forma-síntese". E comenta sobre esses movimentos de ressignificação:

É necessário reconhecer que, se os movimentos de ressignificação e mesmo de adoção e empréstimo de 
atributos identitários - sejam eles elementos de cultura ou de origem-história-memória comuns - são situacionais, os próprios elementos e a possibilidade de operar essas ressignificações, adoções ou empréstimos não o são (...). Mesmo os autores interessados primariamente na diferenciação estrutural de grupo étnico, empregam algum "dado" cultural para definir sua natureza, como aliás é sempre reivindicado pelos próprios observados. A 'plasticidade identitária' formadora desses grupos permite, efetivamente, que eles 'resgatem', 'recuperem', elementos substantivos de identidade que passam a integrar seus processos de emergência, mas como 'matérias-primas' que precisam ser manufaturadas pelas forças mobilizadas no seu interior, na forma de desejos coletivos (ARRUTI, 1997, p. 28).

Fazendo o paralelo do processo de afirmação étnica dos povos indígenas do nordeste com os Arara, arrisca-se inferir que o patrimônio cultural material e imaterial que envolve a memória de Leôncio Arara é este "símbolo", ou "dado cultural" escolhido para garantir a continuidade e a singularidade do grupo, agenciando autorrepresentação tanto para as gerações futuras dos Arara, quanto afirmação étnica para fora da aldeia e a valorização de sua identidade cultural enquanto continuidade de um fluxo, de uma memória que persiste no tempo. 
Espaço Ameríndio

\section{Referências bibliográficas}

ALMEIDA, Fernando O.; GARCIA, Lorena Gomes. Aspectos do Espaço Tupinambá no Leste Amazônico. Revista de Arqueologia, v. 21, n. 2, p. 97-119, 2008.

.; NEVES, Eduardo G. Evidências Arqueológicas para a origem dos Tupi-Guarani no leste da Amazônia. Mana, v. 21, n. 3, p. 499-525, dez. 2015.

ARARA, Adalton. Transcrição de entrevista sobre o Centro de Memória Leôncio Arara. Senador José Porfírio: 13 set. 2019, 13 pgs.

ARARA, Arlindo. Transcrição de entrevista sobre o Centro de Memória Leôncio Arara. Senador José Porfírio: 11 set. 2019, 16 pgs

ARARA, Joselha. Transcrição de entrevista sobre o Centro de Memória Leôncio Arara. Senador José Porfírio: 11 set. 2019, 16 pgs.

ARRUTI, José Maurício A. A emergência dos "remanescentes": notas para o diálogo entre indígenas e quilombolas. Mana, Rio de Janeiro, v. 3, n. 2, p.7-38. 1997

CARNEIRO DA CUNHA, Manuela. Índios no Brasil: história, direitos e cidadania. $1^{\text {a }}$. edição. São Paulo: Ed. Claro Enigma, 2012.

COUDREAU, Henri. Viagem ao Xingu. São Paulo: Editora Edusp, 1977 [1986].

FAUSTO, Carlos. Inimigos Fiéis: História, Guerra e Xamanismo na Amazônia. 1. ed. São Paulo: Edusp, 2001.

GAZONI, Patrícia Maciel. O contemporâneo no museu: os Kaingang e o Museu Histórico e Pedagógico Índia Vanuíre de Tupã (SP), Dissertação (Mestrado em Museologia) - USP, São Paulo, 2014.

GOMES, Alexandre. O. Por uma antropologia dos museus indígenas: práticas de colecionamento, categorias nativas e regimes de memória. Natal: 29ª RBA, 2014.

GORDON, Cesar. Economia selvagem: ritual e mercadoria entre os índios XikrinMebêngôkre. 1. ed. São Paulo: Editora Unesp/ISA/NuTI, 2006.

GRUPIONI, Luís Donisete B. Os museus etnográficos, os povos indígenas e a antropologia: reflexões sobre a trajetória de um campo de relações. In: MAE-USP. Museu, Identidades e Patrimônio Cultural. Rev. do Museu de Arqueologia e Etnologia, São Paulo, Suplemento 7, 2008. p. 21-33.

JURUNA, Lídice. Transcrição de entrevista sobre o Centro de Memória Leôncio Arara. Senador José Porfírio: 12 set. 2019.

KRAUETLER, Eurico, M. O Xingu: encanto ou terror? Belém: Imprimatur, 1953.

MÜLLER, Regina P. Os Asuriní do Xingu: história e arte. 2. ed. Campinas: Editora da 
Espaço Ameríndio

UNICAMP, 1993.

NASCIMENTO, Hilton. Registros históricos da presença dos Juruna e Arara na Volta Grande do Xingu. Altamira: no prelo, 2017.

NIMUENDAJÚ, Curt. Tribes of the Lower and Middle Xingú. In: STEWARD, Julian H. (Ed.). Handbook of South American Indians vol. 3: The tropical forest tribes. Handbook of South American Indians. Washington 1946-1950: Smithsonian Institution, Bureau of American Ethnology, 1948. p. 213-243.

OLIVEIRA, Adélia Engrácia de. Os índios Juruna do alto Xingu. Dedalo. Revista de arte e arqueologia, n. 11-12, p. 1-291, 1970.

PATRÍCIO, Marlinda M. Relatório Antropológico de identificação da terra Indígena Arara da Volta Grande do Xingu (Maia). Brasília: FUNAI, 2005.

Reflexões em torno da vida sociocultural dos Arara da Volta Grande do Xingu frente ao megaempreendimento da Usina Hidrelétrica de Belo Monte. In: OLIVEIRA, J. P. DE; COHN, C. (Eds.). Belo Monte e a questão indígena. 1. ed. Brasília: ABA, 2014. p. 220-238.

PATRÍCIO, Marlinda M. et al. EIA/RIMA AHE Belo Monte, Estudo Socioambiental - Componente Indígena - TI Arara da Volta Grande do Xingu. Engevix/Themag/Intertechne, 2009.

ROCA, Andrea. Acerca dos processos de indigenização dos museus: uma análise comparativa. Mana: Estudos de Antropologia Social, v. 21, n. 1, 2015.

SENADOR JOSÉ PORFÍRIO. O Pai da Mata. Série Oralidade. Senador José Porfírio: SEMED, 2014.

SILVA, Fabíola A. As Tecnologias e seus Significados: um estudo das cerâmicas dos Asuriní do Xingu e da cestaria dos Kayapó-Xikrin sob uma perspectiva etnoarqueológica. 2000. Tese (Doutorado em Antropologia Social) - PPGAS, USP, São Paulo, SP, 2000.

;) NOELLI, Francisco S. Mobility and Territorial Occupation of the Asurini Do Xingu, Pará, Brazil: An Archaeology of the Recent Past in the Amazon. Latin American Antiquity, v. 26, n. 4, p. 493-511, 2015.

STEINEN, Karl. Entre os aborígines do Brasil central. São Paulo: Departamento de Cultura da Cidade de São Paulo, 1940.

TEIXEIRA-PINTO, Márcio. Ieipari: sacrifício e vida social entre os índios Arara (Caribe). São Paulo/Curitiba: Hucitec e Anpocs/Editora UFPR, 1997.

VERTHIC. Censo Populacional da Terra Indígena Arara da Volta Grande do Xingu. 2019. Não publicado. 
Espaço Ameríndio

indígenas Paquiçamba, Arara da Volta Grande do Xingu e Área Indígena Juruna do Km 17. Altamira: Verthic, 2018, 95 pgs.

Artes e artefatos dos Arara da Volta Grande do Xingu. Altamira: Verthic, $2017 \mathrm{a}$, p. 217.

Artes, festas e saberes do povo Arara da Volta Grande do Xingu. Altamira: Verthic, 2017b, 135 pgs.

VERSWIJVER, Gustaaf. The club-fighters of the Amazon: warfare among the Kayapo Indians of Central Brazil. Gent: Rijksuniversiteit te Gent, 1992.

VIDAL, Lux. O museu dos povos indígenas do Oiapoque - kuahí: Gestão do Patrimônio Cultural pelos Povos Indígenas do Oiapoque, Amapá. In: MAE-USP. Museu, Identidades e Patrimônio Cultural. Rev. do Museu de Arqueologia e Etnologia, São Paulo, Suplemento 7, 2008. p.109-115.

VIVEIROS DE CASTRO, Eduardo; ANDRADE, Lúcia M. M. DE. Os povos indígenas do médio Xingu. In: ANDRADE, Lúcia M. M. DE; SANTOS, Leinad A. DE O. (Orgs.). As Hidrelétricas do Xingu e os Povos Indígenas. São Paulo: Comissão Pró-Índio de São Paulo, 1988. p. 135-146.

XAVIER FERREIRA, Eduardo. Asuriní do Xingu: história e etnografia. 2018. Dissertação (Mestrado em Sociologia e Antropologia) - PPGSA, UFRJ, Rio de Janeiro, RJ, 2018. 